\title{
LABOR MARKET EFFECTS OF SPINAL CORD INJURIES IN THE DAWN OF THE COMPUTER AGE
}

\author{
Alan Krueger \\ Douglas Kruse \\ In collaboration with: \\ Susan Drastal
}

Working Paper 5302

\section{NATIONAL BUREAU OF ECONOMIC RESEARCH 1050 Massachusetts Avenue \\ Cambridge, MA 02138 \\ October 1995}

For invaluable assistance in collecting our sample and conducting our survey we thank Herb Abelson, Lynn Firester, Lauren Burnbauer, Dr. Thomas Findley, Judy Macedo, Dr. John Liguoria, Dr. Joseph Stillo, Donna Walters-Kozberg, Tom Jennings, Gail Gilinsky, Christine Martin, and Bill Hopke. Eric Schulz and Nora Villanueva provided excellent research assistance. Monroe Berkowitz, Carol Harvey, Nancy Cantor, Danny Kahneman and seminar participants at the NBER and BLS provided valuable comments. Financial support was provided by New Jersey Developmental Disabilities Council and by the Industrial Relations Section, Princeton University. This paper is part of NBER's research program in Labor Studies. Any opinions expressed are those of the authors and not those of the National Bureau of Economic Research.

(0) 1995 by Alan Krueger and Douglas Kruse. All rights reserved. Short sections of text, not to exceed two paragraphs, may be quoted without explicit permission provided that full credit, including (C) notice, is given to the source. 


\title{
LABOR MARKET EFFECTS OF SPINAL CORD INJURIES IN THE DAWN OF THE COMPUTER AGE
}

\begin{abstract}
What effect does a severe disability have on individuals' employment and earnings? Has the computer revolution lessened the adverse labor market consequences of severe disabilities? This paper investigates the labor market effects of severe, traumatic disabilities resulting from spinal cord injuries (SCIs). We compare the employment experiences of a sample of individuals with SCIs to those of former co-workers over the same period, and to two random samples of individuals in New Jersey. The analysis is based in large part on a 1994 telephone survey of New Jersey adults who had SCIs within the past ten years. Results indicate that the occurrence of an SCI causes a steep decline in employment, hours worked, and weekly earnings, but relatively little change in wage rates for those who work. The computer revolution has the potential to expand employment opportunities for people with disabilities. Our results indicate that having computer skills is associated with higher earnings, and a faster return to work and earnings recovery, for $\mathrm{SCI}$ individuals, after holding constant other variables such as education. There is no apparent earnings gap between SCI and non-SCI computer users, whereas among those who do not use computers at work the earnings of SCI employees lag behind those of nonSCI employees. Despite the benefits, individuals with SCIs are less likely to use computers than the general population.
\end{abstract}

\author{
Alan Krueger \\ Woodrow Wilson School \\ Robertson Hall \\ Princeton University \\ Princeton, NJ 08544-1022 \\ and NBER
}

Douglas Kruse

School of Management and

Labor Relations

Janice $\mathrm{H}$. Levin Building

PO Box 5062

Rutgers University

New Brunswick, NJ 08903-5062

and NBER

Susan Drastal

Kessler Institute for Rehabilitation

1199 Pleasant Valley Way

West Orange, NJ 07052 


\section{Introduction}

Economists have long been interested in the effects of disabilities on individuals' labor market outcomes. Many studies have found that physical disabilities are associated with diminished employment prospects and lower earnings. One limitation of much of this previous literature, however, is that the Census Bureau's question on disability status, which asks individuals if they have a "health condition limiting the kind or amount of work" they can do, virtually assures that individuals classified with a disability have diminished employment and earnings. Additionally, much of the previous literature lumps together very different types of disabilities. In this paper we examine the labor market consequences of a specific, traumatic injury: spinal cord injuries (SCI's). Spinal cord injuries typically result in severe mobility limitations, requiring the use of wheelchairs or crutches on a long-term basis. ${ }^{1}$ Harvey et al. (1992) estimate that 177,000 people in the U.S. had SCI's in 1988, and the SCI population accounts for one-fourth of all wheelchair users under the age of 65 (based on LaPlante et al., 1992 and Harvey, 1990).

This paper has two related goals. The first is to estimate the decline in employment and earnings resulting from the occurrence of an SCI. The second goal involves the impact of the computer revolution on the disability community. The rapid development of computer technologies over the past 15 years has resulted in fundamental changes in American work places. New computer technologies have particularly expanded the range of opportunities available to people with disabilities, both by directly compensating for certain activity limitations and by increasing the value of work that can be done by those with mobility limitations and muscular impairments. Many authors have speculated on the value of computer skills for people with disabilities, but there has been no systematic attempt to assess the value, or even the extent, of computer training and use in the disability community. By focusing on people with SCI's, we study a group for whom computers should be particularly advantageous in the labor market since the impairment restricts employability in many occupations, while computer skills

${ }^{1}$ See DiTunno and Formal (1994) and Trieschmann (1988) for summaries of the medical effects of SCI. 
open up job opportunities in which the impairment is of little or no consequence.

The paper also has a methodological component in that we compare the experiences of a sample of individuals who had an SCI to three alternative comparison groups. Together with Response Analysis Corporation, we first conducted a telephone survey of New Jersey residents with SCI's, asking for information on pre- and post-injury employment, earnings, Social Security numbers (SSN's), computer use, and computer training. In the survey, we asked each SCI person to "nominate" one or two co-workers who worked at a similar job as the SCI person at the time of the injury. ${ }^{2}$ If, for example, the person with an SCI was a painter in 1987 at the time of his injury, the aim was to interview someone who was a fellow painter in 1987, of approximately the same age, in order to compare their subsequent employment experiences. We then tried to interview the nominated co-worker. The second non-SCI comparison group is the general population in March 1994 based on the Annual Demographic File of the Current Population Survey (CPS). The third comparison group consists of a sample of New Jersey residents whose SSN's fell close to those in the SCI sample. The state of New Jersey matched quarterly earnings data from state UI records to our SCI sample and to the sample of nominated co-workers, as well as to the sample whose SSN's were close to those in the SCI sample.

Interestingly, the results are quite robust regardless of the comparison group that we use, and regardless of whether our analysis is based on a pre/postinjury comparison, or just a post-injury comparison. The robustness of our estimates may result because SCI's cause such large employment and earnings declines that any "selection" effects are swamped by the magnitude of the effect of the injury, or because SCI's occur more or less randomly with regard to income and employment. In any event, the occurrence of an SCI appears to lower employment by 40 to 50 percentage points, and weekly earnings by 25 percent. For those who work, however, an SCI appears to have a relatively modest effect on wage rates. The main adverse labor market effects result from a decline in the

${ }^{2}$ The idea of asking a sample to "nominate" its control group has been used occasionally in economics. See, for example, Mincer and Higuchi (1988) and Freeman and Kleiner (1990). 
probability of working and in the number of hours that individuals work, not in the hourly wage they are paid if they do work.

We find that individuals with an SCI are no more likely to use computers at home or at work than are individuals without an SCI. Those who work after suffering an SCI, however, are more likely to use computers at work than the nonSCI sample of workers. Moreover, having used a computer at work prior to injury is associated with a quicker return to work, and with substantially higher pay, among those with an SCI.

\section{Prior Research on Computer Use, Disability, and Employment}

Several studies have found that disability is associated with decreased earnings and employment probabilities (e.g., Berkowitz and Johnson, 1974; Stern, 1989; Haveman and Wolfe, 1989; Famulari, 1992; Johnson and Baldwin, 1994; Daly and Bound, 1995). Many past studies have used the definition of disability from the U.S. Census Bureau, based on whether the respondent has a "health condition limiting the kind or amount of work" he or she can do. Those reporting such a work disability earned, on average, just 638 as much per year as the average earnings of those without a work disability in 1988. As noted earlier, however, it is important to recognize that lower hours and/or earnings are almost part of the definition of disability implied in the question (U.S. Bureau of the Census, 1989). ${ }^{3}$ Another limitation of this definition is that it combines many disparate types of disabilities.

Studies of employment patterns specifically among people with SCI's have found that less than half were employed. Reviewing the literature, Trieschmann (1988) found employment rates ranging from 138 to 488 - consistent with more recent estimates ( 488 in Krause, 1992, and 428 in McShane and Karp, 1993). A representative nationwide sample of people with SCI's found that although 538 had some form of post-injury employment, only 318 were employed at the survey date in 1988-89, and the employment rate did not increase among those who were reinterviewed' in 1992 (Disability Income Systems, 1992a, 1992b). And among

\footnotetext{
${ }^{3}$ See Bound (1991) for an examination of self-reported versus objective measures of health status.
} 
employed people with SCI's, average annual earnings was $\$ 7,263$ in 1988 and $\$ 7,648$ in 1992, or approximately one-third the economy-wide average of wages and salaries per employee. ${ }^{4}$ These average earnings are exceeded by the recurring annual health expenses associated with an SCI, which are estimated at $\$ 14,135$, on average. ${ }^{5}$ Prior research on the employment status of people with SCI's finds that the most important predictors are educational level, age, and time since injury. ${ }^{6}$

Facility with computers may generate large returns to people with disabilities because computer technology can compensate for the physical limitations inherent in many disabilities, and because lack of computer skilis restricts work in many occupations. Computer skills have been mentioned as a primary mechanism for those incurring spinal cord injuries to return to the work place (Bowe, 1987; Disability Income Systems, 1992a). Numerous anecdotal reports attest to the positive impact computers have had on the productivity and potential for earnings among those with disabilities (Modern Office Technology, 1990; Personnel Journal, 1990; Wal1 Street Journal, 1993). Yet no study that we are aware of has yet examined the role of computer skills in economic outcomes for people with disabilities.

Past research clearly illustrates the employment and earnings problems associated with disability, especially SCI. Given the low levels of employment and earnings in the SCI population, and the fact that these individuals are disproportionally drawn from demographic groups that tend to have high employment

${ }^{4}$ The SCI average earnings are from Disability Income Systems (1992a: 22). This survey did not collect data on economy-wide average earnings, so to compare to the overall work force we use data from the National Income and Product Accounts as reported in Survey of Current Business (July 1993). Both of these data series exclude benefits, and include full-time and part-time employees.

${ }^{5}$ This is on top of the initial costs associated with an SCI, which average $\$ 95,203$ for hospitalization and $\$ 8,208$ for home modifications (Harvey et al., 1992: 841).

${ }^{6}$ Summarized in Trieschman (1988: 198-208), and recent studies by Krause (1992), and McShane and Karp (1993). 
rates (e.g., men), one would suspect there is substantial scope for increasing the employability of people with disabilities through computer technology.

\section{Data}

This study is based on data collected from a telephone survey of New Jersey residents with SCI's, carried out for this project by the survey firm Response Analysis Corporation (Princeton, NJ) during August and September, $1994 .{ }^{7}$ Major sections of the survey, which was conducted using a Computer-Aided Telephone Interviewing system, included:

1. Injury characteristics (timing, cause, and severity)

2. Post-injury employment and earnings (employment status, occupation, industry, hours per work, rate of pay, union membership, employer health insurance coverage, and how long after injury until working for pay)

3. Pre-injury employment and earnings (employment status, occupation, industry, hours per work, rate of pay, union membership, employer health insurance coverage)

4. Sources of disability income currently received

5. Computer use and training (whether computer ever used; whether used at home, school, or work; special adaptive devices; timing of first use; whether training ever provided and by whom; timing of first and most recent training)

6. Demographic information (sex, race, marital status, education, age)

7. Social Security number (if not available from patient records)

8. Activities and life satisfaction (whether eight activities engaged in last week, whether voted in last election, and how satisfied with life)

9. Nomination of co-workers from time of injury, with means of contacting them

\footnotetext{
${ }^{7}$ Pre-tests of the questionnaire were conducted in June and July, 1994, using volunteers from outside of New Jersey identified through Craig Rehabilitation Hospital of Colorado (to avoid using people from the sample frame). The survey is described in greater detail in Kruse and Krueger (1995).
} 
The survey's questions on employment closely followed the questions used on the monthly Current Population Survey (CPS). For earnings questions, respondents were asked whether they were paid "hourly, weekly, annually, or on some other basis," and then for the rate of pay on that basis (or their best estimate). In addition, they were asked how many hours per week they would usually work. This information was used to derive hourly and weekly pay. Current and retrospective data were collected. If the reported wage data were not for 1994, they were converted to 1994 values by adjusting for general wage growth using the growth in mean hourly or weekly earnings from the CPS each year.

The sample frame was restricted to people who incurred SCI's within the past 10 years (since January 1, 1984), to increase the reliability of retrospective self-reported data, and to enable pre/post comparisons using state administrative data on earnings. To focus on those who were eligible to be in the full-time work force, additional sample criteria were that the person was at least 15 years old at the time of the injury, and at least 18 years old at the time of the survey. We attempted to identify all New Jersey residents with SCI's in the last 10 years. The majority of the sample came from the patient lists of Kessler Rehabilitation Institute, the main SCI rehabilitation center in New Jersey, including all who had been outpatients or inpatients since 1988 . The Kessler list was supplemented with outpatient lists from JFK Rehabilitation Center, Bachrach Hospital, Lift Inc., and 15 other rehabilitation facilities in New Jersey. ${ }^{8}$ In addition, the New Jersey Division of Vocational Rehabilitation Services sent a letter to all clients with SCI's, soliciting cooperation in the

\footnotetext{
${ }^{8}$ From a list of all rehabilitation centers in New Jersey, contacts were made with 65 that had potential to have SCI clients. Of those that did have SCI clients (many with only one or two), all agreed to supply patient names for this study.
} 
study. This resulted in a final list of 1,118 potentially eligible for the survey. Most SCI patients in the state would have been treated at the Kessler Rehabilitation Institute or one of the smaller rehabilitation centers.

Interviews were successfully completed with 391 of those in the sample frame who were potentially eligible. Seventy individuals refused to respond to the survey, 450 were unreachable ( 82 were unreachable after repeated callbacks, 252 had unpublished or disconnected phone numbers, 60 moved with no way to track, and 56 were known deceased), and 207 were ineligible (not meeting the study criteria or having a language barrier). Of the sample known or estimated to be eligible, the response rate was $568 .{ }^{9}$ Restricting the sample frame to those with usable contact information, the response rate was $818 .{ }^{10}$ of the 391 completions, 91.58 lived in New Jersey at the time of the survey.

The SCI respondents were asked to nominate one or two co-workers from the time of their injury, who could be interviewed to provided a comparison with the experience of the SCI respondent. ${ }^{11}$ of the 370 respondents who were employed pre-injury, 148 nominated a co-worker and provided contact information, and 53 did the same for a second co-worker. ${ }^{12}$ The interviewers attempted to reach 153 of the nominated co-workers (calling the second nominee only if the first nominee

\footnotetext{
${ }^{9}$ Based on completions divided by estimated eligible, using the eligibility ratio from those who were contacted to estimate eligibility of those who were not reachable (excluding the deceased).

${ }^{10}$ Based on estimated usability where contacts were never completed.

${ }^{11}$ Specifically, interviewers asked for someone "who had a position similar to the one you had prior to your injury and is about your age. This person could have had the same employer as you or a different employer."

${ }^{12}$ Those who did not nominate a former co-worker either refused directly (29) or said they could not think of one (160). The latter response may often reflect a disguised refusal to answer the question. In addition, 20 nominated a co-worker but could not provide tracking information, while 34 were not working at the time of their injury.
} 
could not be interviewed). The overall response rate among the estimated eligible sample was 48\%; restricted to those with usable contact information, the response rate was 558.13

For many of the nonrespondents we have some information from medical records and from UI wage records. This enables us to check whether the respondents are unrepresentative of the sample frame, at least along some dimensions. Patient records contain data on gender, race, marital status, age, and age at injury for many in the sample frame. Means and frequencies are reported in Table 1 for the respondents (column 1), for those who refused to participate (column 2), and for those who could not be reached (column 3). The only statistically significant difference between columns 1 and 2 is the length of time since injury: those who refused were more likely to have had recent injuries ( 408 of refusers were injured within the past two years). There were significant differences between respondents and those who were unreachable in terms of their race, marital status, time since injury, and injury severity. The finding on recency of injury may reflect the likelihood of establishing different living arrangements right after an injury: those who were recently injured (many recorded as inpatients) are likely to have moved, while those who are currently recorded as outpatients are more likely to have established stable living arrangements. Similarly, those who are single and paraplegic are more likely to have moved. The statistical analysis takes account of these observable

${ }^{13}$ In a randomly chosen half of the cases, interviewers told the nominated co-worker that the SCI person had nominated him or her for the study. The response rate for the estimated eligible sample was 518 when the SCI person's name was used, and 448 when it was not; restricted to the sample with usable contact information, the response rate was $59 \%$ when the SCI person's name was used and $48 \%$ when it was not. 
TABLE 1: Respondent vs. Non-respondent Characteristics

\begin{tabular}{|c|c|c|c|c|}
\hline & & $\begin{array}{l}\text { Respondents } \\
\text { (1) }\end{array}$ & $\begin{array}{l}\text { Refused } \\
\text { (2) }\end{array}$ & $\begin{array}{l}\text { Not reached } \\
\text { or not usable^ } \\
\text { (3) }\end{array}$ \\
\hline \multicolumn{2}{|l|}{ Total number } & 391 & 70 & 400 \\
\hline Gender & $\begin{array}{l}\text { Male } \\
\text { Female }\end{array}$ & $\begin{array}{l}69.1 x \\
30.9 x\end{array}$ & $\begin{array}{l}72.7 x \\
27.3 x\end{array}$ & $\begin{array}{l}73.2 \% \\
26.8 \%\end{array}$ \\
\hline Race & $\begin{array}{l}\text { White } \\
\text { Black } \\
\text { Other }\end{array}$ & $\begin{array}{l}69.1 x \\
20.74 \\
10.2 \%\end{array}$ & $\begin{array}{l}76.8 \% \\
19.6 \% \\
3.6 \%\end{array}$ & $\begin{array}{l}51.8 \% * \\
35.3 \% * \\
12.9 \% *\end{array}$ \\
\hline Marital status & $\begin{array}{l}\text { Single } \\
\text { Married, sp. present } \\
\text { Separated/divorced }\end{array}$ & $\begin{array}{l}44.8 \% \\
36.4 \% \\
16.2 \%\end{array}$ & $\begin{array}{r}45.8 \% \\
43.8 \% \\
8.3 \%\end{array}$ & $\begin{array}{l}60.6 \% \star \\
26.3 \%^{*} \\
10.6 \%\end{array}$ \\
\hline \multirow[t]{2}{*}{ Age } & Mean & 38.8 & 41.6 & 39.1 \\
\hline & $\begin{array}{l}16-30 \\
31-44 \\
45+\end{array}$ & $\begin{array}{l}45.6 x \\
30.8 x \\
23.6 x\end{array}$ & $\begin{array}{l}38.2 \% \\
27.3 \% \\
34.6 \%\end{array}$ & $\begin{array}{l}47.0 \% \\
31.0 \% \\
22.0 \%\end{array}$ \\
\hline \multirow[t]{2}{*}{ Time since injury } & Mean & 4.7 & $3.4 *$ & $3.7 \star$ \\
\hline & $\begin{array}{l}0-2 \\
2-4 \\
4-7 \\
7-10\end{array}$ & $\begin{array}{l}20.5 \% \\
24.9 \% \\
34.1 \% \\
20.5 \%\end{array}$ & $\begin{array}{r}40.0 \% \\
34.6 \% \\
16.4 \% \\
9.1 \%\end{array}$ & $\begin{array}{r}36.9 \% \\
29.1 \% \\
25.8 \% \\
8.2 \%\end{array}$ \\
\hline Severity & $\begin{array}{l}\text { Quadriplegic } \\
\text { Paraplegic }\end{array}$ & $\begin{array}{l}48.6 \% \\
51.4 \%\end{array}$ & $\begin{array}{l}43.9 \% \\
56.1 \%\end{array}$ & $\begin{array}{l}38.3 \% * \\
61.7 \% *\end{array}$ \\
\hline
\end{tabular}

Based on SCI patient records from Kessler Rehabilitation Institute.

* Significant difference from respondent group at p<.05 (using $t$-test for

cont inuous variables, chi-squared for categorical variables)

Disconnected or unlisted number, or moved, with no way to track (may not have been eligible under study criteria). 
differences by explicitly estimating and controlling for the effects of these characteristics on the employment and earnings variables of interest.

The question of disability in the general population is touched on by two measures in the CPS. First, each month those who did not work in the survey week can respond that they were unable to work, and can give "ill health, physical disability" as a reason for not looking for work. The March 1994 CPS indicates that 2.88 of all individuals report a disability as a reason for not working, compared to 10.38 of the SCI sample when we asked the same set of questions. Obviously, this series of questions misses many people who have severe disabilities. Second, the March CPS asks whether the respondent has a "health condition preventing work, or limiting the kind or amount of work (s/he) can do." Eight percent of the general population of New Jersey report such a work disability in March 1994. We asked the same question of the paired non-SCI sample, and found that 15.58 reported having a work disability.

\section{Administrative Earnings Data}

It is perhaps unreasonable to expect respondents to report accurate information on employment and earnings for periods up to 10 years in the past. Fortunately, the New Jersey Department of Labor provided quarterly earnings records for those individuals for whom $\mathrm{SSN}^{\prime} \mathrm{s}$ were available. These data have two key advantages. First, although the survey collects data for only two time periods (most recent pre- and post-injury), the earnings records can be used to look at quarterly earnings every quarter up to 10 years before and after the injury. A second advantage is that these are administrative data, not subject to errors from faulty memories or recall bias of survey respondents. On the 
other hand, the administrative records are confined to covered employment, and do not cover employees who work in other states.

For cases in which the SSN was not available from patient records, the respondent was asked for his or her SSN. The total available SSN's for people with SCI's was 638 , including 358 survey respondents ( 92.68 of all respondents), 50 refusers ( 71.48 of all refusers), and 230 of those who could not be reached ( 57.88 of the total in this group). To generate a large non-SCI comparison group, for each person with an SCI who was born in New Jersey we constructed a window of plus or minus 10 numbers around the SCI person's SSN, and any person with an SSN that fell within this window had their earnings records pulled as we11. For those who were not born in New Jersey, the window was widened to plus or minus $50 \mathrm{SSN}^{\prime} \mathrm{S}$, due to the lower likelihood of capturing non-SCI people.

These SSN's were used to extract quarterly earnings records reported under the New Jersey Unemployment Insurance/Disability Insurance (UI/DI) system between the second quarter of 1985 (the earliest available) and the third quarter of 1994. Since New Jersey wages are subject to payroll taxes for the UI/DI system, these reports are mandatory and the records should cover all individuals working for New Jersey employers at any time in this period. The numbers of SSN's that matched an earnings record in at least one quarter were: 270 survey respondents ( 75.48 of the 358 respondents with S.S. numbers available), 36 survey refusers (72.08 of the 50 S.S. numbers in this group), 157 of those who could not be reached ( 68.38 of the $230 \mathrm{~S} . \mathrm{S}$. numbers in this group), and 5,073 people in the general population.

The administrative earnings records also can be used to compare the earnings and covered employment rates of respondents and nonrespondents. Such a comparison shows that respondents are slightly more likely to have covered 
employment prior to the injury than those who refused to respond or were unreachable ( 758 versus 728 and 688 , respectively), and more likely to have covered employment after the injury as well (398 versus 318 and 278 ). Average quarterly earnings for survey respondents in the most recent four quarters with earnings prior to the injury was $\$ 5,404$, compared to $\$ 5,206$ for survey refusers and $\$ 4,770$ for those who were not reached. of these estimates, only the employment rate for the unreachable differs significantly from that of the respondents, probably because the survey respondents are more likely to live in New Jersey. Overall, however, the administrative data do not reveal gross differences between the survey respondents and nonrespondents.

\section{Demographic and Injury Characteristics}

Table 2 summarizes the demographic and injury characteristics of the SCI sample and several comparison groups. Results for the full SCI sample are provided in column 1, with results for the SCI and non-SCI paired samples in columns 2 and 3 . Two useful comparison groups are a nationally-representative SCI sample (column 4) collected by Berkowitz, et al. (1992), and the general adult population of New Jersey (age 18t, in column 5, based on the March 1994 CPS).

In the full SCI sample, over two-thirds (69.1\%) are male, which is close to the national average ( 71.08 in column 4), and clearly higher than the New Jersey population (47.98, column 5). This reflects men's higher participation in the kinds of activities that can lead to SCI's, including manual jobs, sports, and unsafe driving. Although 89.48 of the national SCI group is white, which corresponds closely to the national average for the general population, the percentage classifying themselves as white in our SCI sample (68.98) was lower 
TABLE 2: Demographic and Injury Characteristics

\begin{tabular}{|c|c|c|c|c|c|c|}
\hline & \multicolumn{2}{|c|}{$\begin{array}{l}\text { Full SCI } \\
\text { sample } \\
\text { (1) }\end{array}$} & \multicolumn{2}{|c|}{$\begin{array}{l}\text { Paired Sample } \\
\text { SCI } \\
\begin{array}{ll}(2) & \text { Non-SCI } \\
\text { (3) }\end{array}\end{array}$} & $\begin{array}{l}\text { National SCI } \\
\text { sample, } 1988^{\star} \\
(4)\end{array}$ & $\begin{array}{l}\text { General Population, } \\
\text { N.J.1994** } \\
\text { (5) }\end{array}$ \\
\hline $\begin{array}{l}\text { Sample size } \\
\text { Gender }\end{array}$ & Male & $\begin{array}{l}391 \\
69.1 \%\end{array}$ & $\begin{array}{c}71 \\
69.0 \%\end{array}$ & $\begin{array}{c}71 \\
63.4 x\end{array}$ & $\begin{array}{c}758 \\
71.0 x\end{array}$ & $\begin{array}{l}4805 \\
47.97\end{array}$ \\
\hline Race & $\begin{array}{l}\text { White } \\
\text { Black } \\
\text { Asian } \\
\text { Other }\end{array}$ & $\begin{array}{r}68.9 \% \\
20.8 \% \\
2.3 \% \\
7.9 \%\end{array}$ & $\begin{array}{r}70.4 x \\
18.3 x \\
5.7 x \\
4.2 \%\end{array}$ & $\begin{array}{r}71.0 x \\
18.8 x \\
4.4 x \\
5.8 x\end{array}$ & $89.4 x$ & $\begin{array}{r}83.7 \% \\
11.9 \% \\
3.2 \% \\
1.2 \%\end{array}$ \\
\hline Marital status & $\begin{array}{l}\text { Married, sp. present } \\
\text { Separated/divorced } \\
\text { Single }\end{array}$ & $\begin{array}{l}36.3 x \\
16.1 x \\
44.8 x\end{array}$ & $\begin{array}{l}43.7 \% \\
16.9 \% \\
35.2 \%\end{array}$ & $\begin{array}{r}61.4 x \\
8.4 x \\
25.4 x\end{array}$ & & $\begin{array}{r}55.8 \% \\
9.4 \% \\
28.0 \%\end{array}$ \\
\hline \multirow[t]{2}{*}{ Education } & $\begin{array}{l}\text { No high school degree } \\
\text { High school degree } \\
\text { Some college } \\
\text { College degree } \\
\text { Graduate degree }\end{array}$ & $\begin{array}{r}15.9 \% \\
27.4 \% \\
31.3 \% \\
18.2 \% \\
7.2 x\end{array}$ & $\begin{array}{l}16.9 \% \\
19.7 \% \\
29.6 \% \\
18.3 \% \\
15.5 \%\end{array}$ & $\begin{array}{l}21.1 \% \\
28.27 \\
18.34 \\
18.3 \% \\
14.1 \%\end{array}$ & $\begin{array}{r}16.7 x \\
31.5 \% \\
25.3 x \\
26.5 \% \mathrm{w} / \mathrm{coll} \text { ege } \\
\text { or grad. degree }\end{array}$ & $\begin{array}{r}16.3 \% \\
36.3 \% \\
16.8 \% \\
22.7 \% \\
8.0 \%\end{array}$ \\
\hline & Currently student & $14.8 x$ & $8.5 x$ & 9.97 & & \\
\hline Age & Mean & 38.5 & 42.3 & 41.6 & & 44.6 \\
\hline Age at injury & $\begin{array}{l}\text { Mean } \\
0-15 \\
16-30 \\
31-44 \\
45+\end{array}$ & $\begin{array}{l}33.8 \\
1.3 \% \\
44.5 \% \\
31.3 \% \\
22.9 \%\end{array}$ & $\begin{array}{l}38.5 \\
0.0 \% \\
35.2 \% \\
26.8 \% \\
38.0 \%\end{array}$ & & $\begin{array}{l}7.6 \% \\
49.4 \% \\
24.3 \% \\
17.5 \%\end{array}$ & \\
\hline Cause of injury & $\begin{array}{l}\text { Fall } \\
\text { violence } \\
\text { Sports/diving } \\
\text { Pedestrian } \\
\text { Vehicle } \\
\text { Other }\end{array}$ & $\begin{array}{r}14.8 \% \\
9.2 \% \\
13.6 \% \\
3.1 \% \\
31.2 \% \\
18.4 \%\end{array}$ & $\begin{array}{r}18.3 \% \\
7.0 \% \\
14.1 \% \\
1.4 \% \\
28.2 \% \\
31.0 \%\end{array}$ & & $\begin{array}{r}16.8 \% \\
5.2 \% \\
16.3 \% \\
2.0 \% \\
45.4 \% \\
11.6 \%\end{array}$ & \\
\hline Severity & $\begin{array}{c}\text { Paraplegic } \\
\text { Complete } \\
\text { Incomplete } \\
\text { Quadriplegic } \\
\text { Complete } \\
\text { Incomplete }\end{array}$ & $\begin{array}{l}51.1 \% \\
25.5 \% \\
24.5 \% \\
48.9 \% \\
19.1 \% \\
28.4 \%\end{array}$ & $\begin{array}{l}50.0 \% \\
27.9 \% \\
22.1 \% \\
50.0 \% \\
19.1 \% \\
30.9 \%\end{array}$ & & $\begin{array}{l}55.5 \% \\
21.8 \% \\
33.7 \% \\
43.7 \% \\
20.9 \% \\
22.8 \%\end{array}$ & \\
\hline $\begin{array}{l}\text { Other long-term } \\
\text { injuries with SCI } \\
\text { Can drive car } \\
\text { Can dial phone }\end{array}$ & $\begin{array}{l}\text { Sterming from } \mathrm{SCl} \\
\text { In addition to } \mathrm{SCl}\end{array}$ & $\begin{array}{r}3.1 \% \\
11.8 \% \\
70.0 \% \\
89.0 \%\end{array}$ & $\begin{array}{r}5.6 \% \\
11.3 \% \\
69.0 \% \\
93.0 \%\end{array}$ & & & \\
\hline
\end{tabular}

ial phone

* Berkowitz et al. (1992) \#\# Current Population Survey respondents age 18 or over, March 1994. Weighted

means were calculated from the CPS. 
than for the New Jersey general population (83.78). ${ }^{14}$ People with SCI's are less likely to be married with a spouse present ( 36.38 ) than those in the non-SCI paired sample (61.48) or in the general population (55.88). They were almost twice as likely to be separated or divorced ( 16.18 compared to 9.48 in the general population), and much more likely to never be married ( $44.8 \%$ compared to 28.08 in the general population). This probably reflects the marital difficulties encountered by people with SCI's. For example, a study by DeVivo and Fine (1985) that follows people with SCI's for three years after their injury, finds that the marriage rate was only one-third, and the divorce rate was more than double what would have been expected based on the general population The educational data show that in the SCI sample the percentages with college degrees (18.2) or graduate degrees (7.28) are similar to those in the general population ( 22.78 and 8.08 , respectively), but the percentage who have gone beyond high school to take some college classes, without completing a degree, is higher. In the full SCI sample, 14.88 are students (full- or parttime), but the percentage is similar between the SCI and non-SCI pairs ( $8.5 \%$ and 9.98).

The mean age in the SCI sample is just under 39 years, six years lower than the mean for the general adult population. The lower mean age for this sample reflects two factors: the young age at which SCI's typically occur, and the sampling scheme which is restricted to people who have been injured in the past 10 years. The mean age at which injuries occurred is 33.8 , with the greatest portion occurring in the 16-30 age bracket (44.58, comparable to figures for the

\footnotetext{
${ }^{14}$ Part of the discrepancy comes from the fact that 18 respondents $(4.68)$ in the current study would classify themselves only as "Hispanic", which is not generally defined as a race. In the March 1994 CPS, 908 of Hispanics are also classified as white.
} 
national SCI sample). The disproportionate number of accidents in this age bracket (in which only 21.68 of the U.S. general population falls) probably reflects higher participation in the kinds of activities that lead to SCI's.

The most common causes of SCI's in this sample were vehicular accidents ( 31.28 in a vehicle and 3.18 as pedestrians), falls (14.88), sports/diving accidents (13.68), acts of violence (9.28), and medical/surgical complications (9.28). There is a gender difference in the causes of SCI, as well in their prevalence: compared to men, smaller percentages of women were injured in sports/diving accidents, acts of violence, or vehicular accidents as the driver, and larger percentages were injured in medical/surgical complications or vehicular accidents as a passenger.

The severity of spinal cord injury is classified along two dimensions: the level of the spinal cord at which the injury occurs, and whether the injury results in a complete severing of the cord. While all SCI's result in impairment of the legs, people receiving injuries in the neck (quadriplegics) generally lack some or any strength and dexterity in arms and hands, while those injured in the back (paraplegics) generally have full use of arms and hands. When the injury is "complete" the person lacks any sensation or muscle use below the level of the injury, whereas someone with an "incomplete" injury may have some sensation and muscle use. Respondents were asked if they have any muscle use below the level of the injury, and if so, whether this use is of some functional value. If reported to be of some functional value, the injury is recorded here as "incomplete".

Respondents were evenly split between paraplegics (5l.18) and quadriplegics (48.98), with a slightly higher prevalence of quadriplegia than in the national sample (43.78). They were also almost evenly split between complete and 
incomplete injuries, resulting in roughly equal groups for the four permutations: complete paraplegics (25.58), incomplete paraplegics (24.58), complete quadriplegics (19.18), and incomplete quadriplegics (28.48).

There may be complications stemming from an SCI (e.g., blood clots, pressure sores), or additional injuries occurring from the accident that caused the SCI (e.g., head injuries, lost limbs, hearing or vision loss). Asked if they had received other long-term injuries at the time of the SCI, 3.18 reported conditions that commonly stem from an SCI, and 11.88 reported additional injuries .

Finally, two functional abilities which are likely to be important for employment and computer use were measured. Respondents were asked, "Are you currently able to drive a car or van, if you need to?" and, "Can you dial a touch tone phone without special adaptive devices?" A majority (708) reported being able to drive a car or van, and even more ( 898 ) reported being able to dial a phone without special adaptive devices. The high proportion of SCI people who can operate a phone suggests that a high proportion is physically able to operate a computer with only minimal adaptations.

\section{Employment Effects of SCI}

Individuals who have suffered an SCI have low employment rates. As shown in Table 3, only $30 \%$ of the SCI sample was employed at the time of the survey. This closely matches the employment rate from the national SCI sample (33\%, in column 5) and is just under half the rate for the New Jersey adult population (628, in column 4). ${ }^{15}$ The employment rate among the nominated pairs of the SCI

\footnotetext{
${ }^{15}$ If the N.J. sample is limited to those between age 18 and 64 , the employment rate rises to 748 .
} 
TABLE 3: Employment Rates, SCI Sample and Comparison Groups

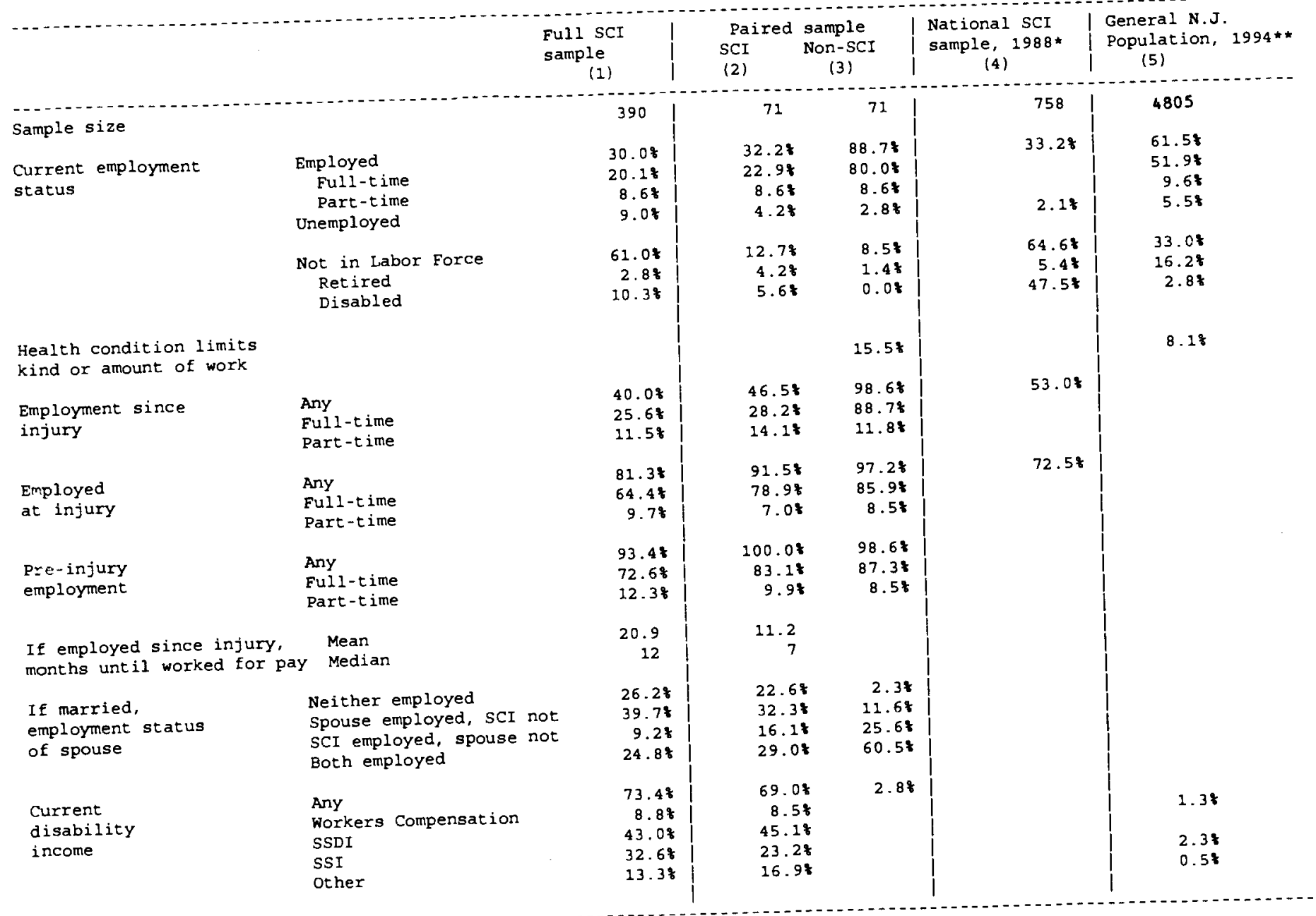

* Berkowitz et al. (1992)

Berkowitz et al. (1992) 
sample is 898 . Of the employed people with SCI's, two-thirds work full-time, compared to five-sixths of those employed in the general population. A larger share of the SCI sample reports being unemployed (9.08) than in the general population (5.58). Those who are out of the labor force account for 61.08 of the SCI sample compared to only 33.08 of the general N.J. population. Given the low employment rates, it is perhaps surprising that nearly half of the non-working SCI sample replied that it was very or somewhat likely they "will be employed three years from now."

A large majority of the SCI sample had pre-injury employment: 81.38 were employed at the time of the injury, and an additional 12.18 reported employment prior to that time. Less than half (40\%) have had any employment since the infury, and only one-fourth (25.6\%) have had full-time employment. The national SCI sample indicates 538 with post-injury employment. One reason our sample may have a lower employment rate is because we restrict the sample to those who had an injury within the past 10 years, which provides less time for subsequent employment. For those who did work post-injury, it took from zero months to six years to begin employment after the infury, with a mean of almost two years (20.9 months) and a median of exactly one year.

A severe disability such as SCI will often qualify one for disability income. This is an important issue since such income provides not only an alternative source of support, but is often tied to the employability and employment status of the individual. Disability benefits often are unavailable or reduced if the person is employed or employable. In the SCI sample, almost three-fourths (73.48) report some form of disability income. The most common sources are Social Security Disability Income (SSDI) and Supplemental Security Income (SSI). Workers' Compensation payments, for work-related injuries, are 
reported by 8.88 of the sample, and 13.38 report some other form of disability income (the most common are company, union, or private insurance). In our sample, of those who receive no disability income, $67.3 \%$ are currently employed, while only 16.38 of those who receive any form of disability income are currently employed. The employment rates do not differ greatly by the source of disability income. Although these numbers clearly confirm a negative relationship between disability income and employment, it should be emphasized that this does not establish a causal relationship. Those with more severe disability and restricted employment opportunities are more likely to be eligible for disability income, while the availability of disability income in turn affects the costs and incentives for employment (in particular, some payments are contingent on not working). Because of the endogeneity of disability income, we do not include it as an explanatory variable in our employment and earnings equations.

In Table 4 we present estimates of several probit equations for the SCI sample, where the dependent variable is an indicator of whether the individual currently works, or worked since his or her injury. The probit coefficients have been transformed into changes in the employment probability associated with oneunit changes in each variable, assuming all other variables are at their mean values. The results indicate that education is a strong predictor of employment status, with college graduates much more likely to be currently employed or employed since their injury than those without high school degrees.

Injury severity also matters greatly: compared to incomplete paraplegics, the predicted current employment is lower for complete paraplegics ( 15 points), incomplete quadriplegics (13 points), and complete quadriplegics (22 points). Interestingly, much of the negative influence of injury severity may be due to Inability to drive an automobile or dial a telephone. Columns 2 and 5 indicate 
Table 4: Determinants of Probability of Employment, SCI sample

Note: Numbers represent estimated effects on probabilities, based on probit models. See below for interpretation.

\begin{tabular}{|c|c|c|c|c|c|c|c|c|c|c|c|}
\hline Dependent variable: & $\begin{array}{r}\text { Employed } \\
\text { (1) }\end{array}$ & Now & $\begin{array}{l}\text { Empl oye } \\
\text { (2) }\end{array}$ & (2) & Empl oy & yed Now & $\begin{array}{l}\text { Employed Since } \\
\text { Injury } \\
(4)\end{array}$ & Emplo & $\begin{array}{l}\text { oyed since } \\
\text { njury } \\
\text { (5) }\end{array}$ & Employ & $\begin{array}{l}\text { yed since } \\
\text { jury } \\
(6)\end{array}$ \\
\hline $\begin{array}{l}\text { Demographics: } \\
\text { Age }\end{array}$ & -0.003 & $(1.24)$ & -0.003 & $(1.13)$ & -0.002 & $(0.87)$ & $(0.66)$ & -0.001 & $(0.38)$ & -0.001 & $(0.44)$ \\
\hline Female & -0.031 & $(0.55)$ & -0.001 & $(0.02)$ & -0.002 & $(0.03)$ & $-0.110 * *(1.75)$ & -0.075 & (1.13) & -0.080 & $(1.17)$ \\
\hline $\begin{array}{l}\text { Black } \\
\text { Othrace }\end{array}$ & $\begin{array}{l}-0.158 * * \\
-0.017\end{array}$ & $\begin{array}{l}(2.31) \\
(0.21)\end{array}$ & $\begin{array}{l}-0.139 * \star \\
-0.015\end{array}$ & $\star \begin{array}{l}(2.05) \\
(0.19)\end{array}$ & $\begin{array}{l}-0.139 \\
-0.040\end{array}$ & \#* $\begin{array}{l}(1.98) \\
(0.51)\end{array}$ & $\begin{aligned}-0.160 * * & (2.15) \\
0.057 & (0.59)\end{aligned}$ & $\begin{array}{r}-0.145 \\
0.052\end{array}$ & $\begin{array}{l}(1.91) \\
(0.53)\end{array}$ & $\begin{array}{c}-0.138 * \\
0.031\end{array}$ & $\begin{array}{l}(1.73) \\
(0.31)\end{array}$ \\
\hline $\begin{array}{l}\text { H.S. grad } \\
\text { Some coll lege } \\
\text { College grad } \\
\text { Grad work }\end{array}$ & $\begin{array}{l}0.140 \\
0.281 * * * \\
0.561 * * * \\
0.524 * * \star\end{array}$ & $\begin{array}{l}(1.29) \\
(2.75) \\
(5.04) \\
(3.96)\end{array}$ & $\begin{array}{l}0.118 \\
0.274 * \star \\
0.505 * \star \\
0.551 * \star\end{array}$ & $\begin{array}{r}(1.08) \\
* \star \star(2.60) \\
* \star *(4.30) \\
* \star \star(3.94)\end{array}$ & $\begin{array}{l}0.103 \\
0.245 \\
0.478 \\
0.505\end{array}$ & $\begin{array}{r}(0.91) \\
\star \star \star(2.26) \\
\star \star \star(3.90) \\
\star \star \star(3.43)\end{array}$ & $\begin{array}{l}0.256 *(2.24) \\
0.424 * *(4.02) \\
0.610 * \pi(5.82) \\
0.607 * \pi(5.28)\end{array}$ & $\begin{array}{l}0.234 \\
0.426 \\
0.570 \\
0.637\end{array}$ & 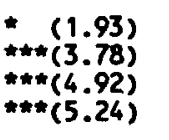 & $\begin{array}{l}0.225 * \\
0.414 * \\
0.555 * \\
0.616 \text { * }\end{array}$ & $\begin{array}{r}(1.82) \\
\star \star \star(3.58) \\
\star \star \star(4.62) \\
\star \star \star(4.85)\end{array}$ \\
\hline $\begin{array}{l}\text { Injury characteristics } \\
\text { Complete para } \\
\text { Incom. quad } \\
\text { Complete quad }\end{array}$ & $\begin{array}{l}-0.153 * \star \\
-0.141 * * \\
-0.228 * \star *\end{array}$ & $\begin{array}{l}(2.41) \\
(2.24) \\
(3.40)\end{array}$ & $\begin{array}{l}-0.119 \\
-0.088 \\
-0.139\end{array}$ & $\begin{array}{r}(1.89) \\
(1.38) \\
(1.87)\end{array}$ & $\begin{array}{l}-0.135 \\
-0.090 \\
-0.139\end{array}$ & $\begin{array}{l}\text { \#* }(2.12) \\
(1.38) \\
+\quad(1.81)\end{array}$ & $\begin{array}{l}-0.145 * \quad(1.91) \\
-0.121 \quad(1.64) \\
-0.286 * *(3.61)\end{array}$ & $\begin{array}{l}-0.103 \\
-0.057 \\
-0.158\end{array}$ & $\begin{array}{r}(1.32) \\
+\quad(0.73) \\
(1.75)\end{array}$ & $\begin{array}{l}-0.114 \\
-0.057 \\
-0.152\end{array}$ & $\begin{array}{l}(1.43) \\
(0.73) \\
(1.63)\end{array}$ \\
\hline Yrs. since injury & 0.015 & $(1.54)$ & 0.006 & $(0.64)$ & 0.007 & $(0.67)$ & $0.035 * * *(3.14)$ & 0.023 & $*(2.03)$ & $0.021 *$ & $\star(1.78)$ \\
\hline $\begin{array}{l}\text { Abilities } \\
\text { Can drive }\end{array}$ & & & $0.257 *$ & $* * *(3.75)$ & 0.257 & $* * \pi(3.62)$ & & 0.336 & $(4.41)$ & $0.339 *$ & $* \star *(4.23)$ \\
\hline Can dial & & & 0.100 & $(0.88)$ & 0.077 & $(0.63)$ & & 0.112 & $(0.93)$ & 0.059 & $(0.44)$ \\
\hline $\begin{array}{c}\text { Computer use pre-injury } \\
\text { Any use at work }\end{array}$ & & & & & 0.054 & $(0.84)$ & & & & 0.043 & $(0.58)$ \\
\hline Used but not at work & & & & & 0.062 & $(0.79)$ & & & & -0.020 & $(0.23)$ \\
\hline $\begin{array}{l}\text { Dependent variable mean } \\
\text { Log-likel ihood } \\
\text { Pseudo-R-squared } \\
\text { n }\end{array}$ & $\begin{array}{r}0.307 \\
-180.83 \\
0.181 \\
358\end{array}$ & & $\begin{array}{r}0.309 \\
-165.87 \\
0.240 \\
353\end{array}$ & & $\begin{array}{r}0.310 \\
-160.490 \\
0.235 \\
339\end{array}$ & & $\begin{array}{r}0.408 \\
-194.62 \\
0.207 \\
363\end{array}$ & $\begin{array}{r}0.411 \\
-176.47 \\
0.272 \\
358\end{array}$ & & $\begin{array}{r}0.416 \\
-172.450 \\
0.262 \\
344\end{array}$ & \\
\hline
\end{tabular}

Note: Dependent variables are whether the SCI person is employed now (cols. 1-3), or has been employed since the injury (cols. 4-6).

Presented estimates represent the change in the percentage point probability of employment for a

one-unit change in the independent variable, assuming other variables are at mean value.

Samplé restricted to those under age 65 in colums $1-3$, and those injured before age 65 in colums 4-6.

*p<.10 **p<.05 *** p<.01 (two-tailed) 
that the ability to drive is exerts a very strong effect on employment, whereas the ability to dial a phone does not have a significant effect. Furthermore, when these ability differences are accounted for, the effects of injury severity remain negative but are much smaller, suggesting that much of the employment disadvantage associated with greater injury severity is associated with the inability to drive.

Length of time since the injury is not a statistically significant predictor of being currently employed, but it is a significant predictor of having had any employment since the injury. The probability of ever working increases by 3.5 percentage points for each year since the injury, however. This result should not come as a surprise because more time probably provides more opportunity to find work and rehabilitate.

Does pre-injury facility with computers influence employment prospects after an SCI? We focus on pre-injury rather than post-injury computer use because post-injury computer use is often a product of current employment. For those who used a computer at work prior to their injury, 548 have been employed since their injury, and $43.1 \%$ are currently employed. The employment rates are lower for those who first used a computer before the injury, but not at work (38.08 with any post-injury employment and 31.08 currently employed), and lower still for those who never used a computer prior to the injury (34.58 with any post-injury employment and 23.58 currently employed). Estimates presented in columns 3 and 6 of Table 4, however, indicate that pre-injury computer use has an insignificant, positive relationship with the probability of employment, once education, gender, and other variables are accounted for.

An alternative to the probit model that we tried was to estimate duration models of how long it takes for an individual to return to work (or find work) 
after incurring a spinal cord injury, treating workers who have yet to return to work or never return to work as censored spells. In results reported in Table 18 of Kruse and Krueger (1995), we estimated a Weibull model of time until employment. In general, these results were qualitatively similar to the probit models: race, education, and injury severity were highly significant predictors of the duration until employment. In addition, those who used a computer in preinjury work had a speedier return to employment, with a 548 higher chance of becoming re-employed in any given month, compared to those who had no pre-injury computer use.

\section{Employment Rate of SCI Sample vs. General Population}

How do these determinants of employment compare to the determinants of employment in the general population of New Jersey? Estimates of employment equations for the two samples are shown in Table 5, using a common set of explanatory variables. This table reports both the predicted probabilities of employment for those with certain characteristics (assuming mean values on all variables other than that characteristic), and the difference in probability from a base group (exploring the difference by sex, race, marital status, and educational level). The samples are limited to those age 18 to 64 .

The strongest similarity between the general population and the SCI sample (columns 1 and 2 ) is the positive influence that education has on the probability of current employment. Education appears to be more valuable, however, for those with SCI's. ${ }^{16}$ The predicted employment rate for an SCI individual with a

\footnotetext{
${ }^{16}$ There is a statistically significant difference $(\mathrm{p}<.05)$ between the samples in the effects of higher education, based on statistical tests comparing the differences between the "high school grad" and "some college" coefficients, and the "college grad" and "some college" coefficients.
} 
Table 5: Determinants of Probability of Employment,

SCI Sample Compared to General Population

Note: Numbers represent estimated probabilities, or differences in probabilities, based on probit models. See note below.

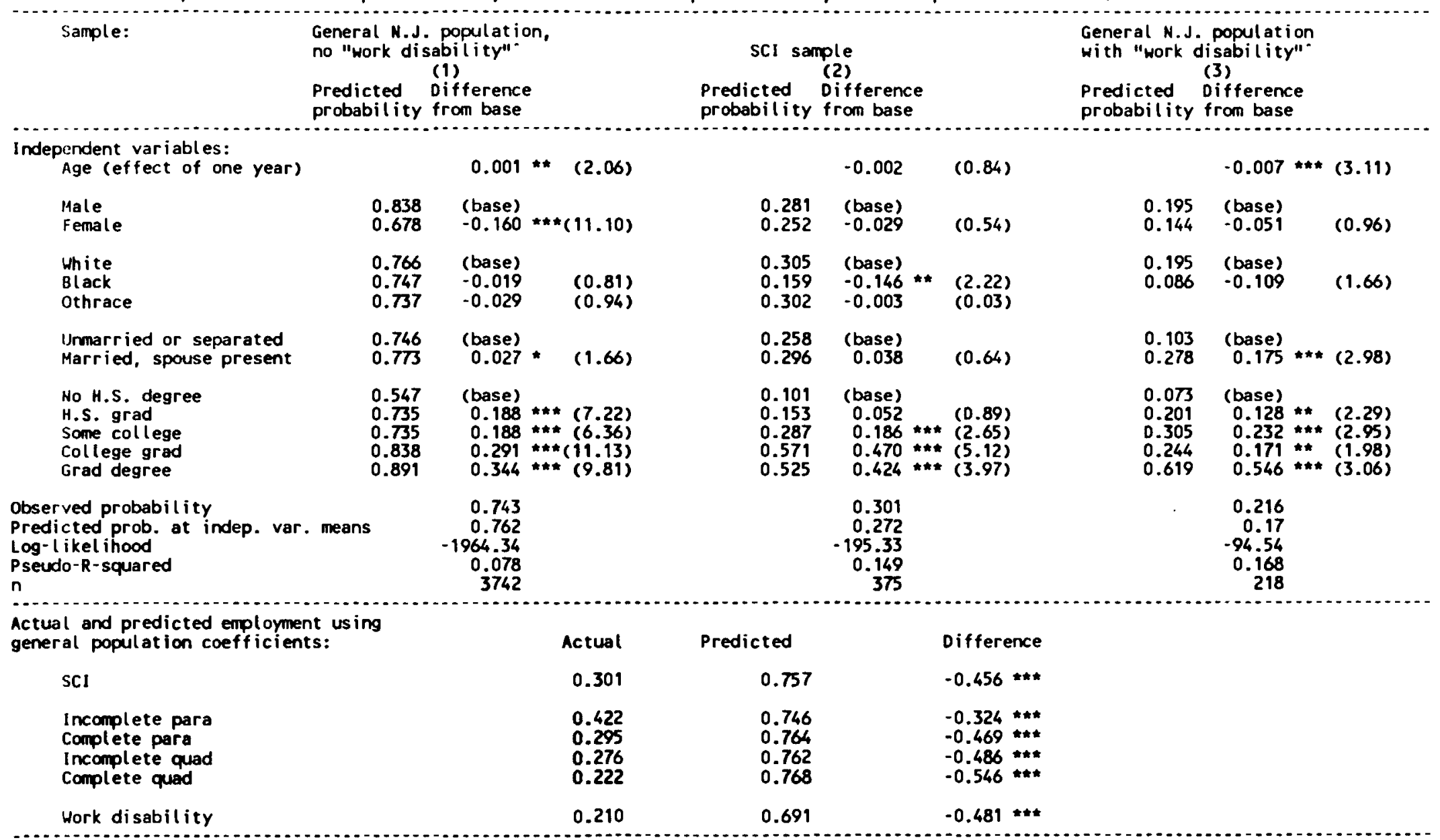

Note: Dependent variable is current employment. Sample restricted to those age 18-64.

Predicted values represent the predicted probability for someone with that characteristic, assuming other variables are

at mean values. Difference from base represents that group's prediction minus base group's prediction.

* P<. 10 * $0<05$ ** P<. 01 (two-tailed) (T-statistics in parentheses)

"Work disability" = respondent reports a heal th condition that prevents working, or restricts the kind

or amount of work that can be done (reported for 5.74 of the surveyed general population age 18-64). 
college degree $(578)$ is almost four times the predicted rate for an SCI individual with no more than a high school degree (15\%), compared to a more modest difference in the general population ( 848 versus 748 ). Put another way, an SCI appears to moderately lower the employment rate of college graduates, but to severely restrict the employment of those who did not go beyond high school. There are also noteworthy differences in other determinants of employment. Women and younger workers are strongly predicted to have lower employment in the general population (a 16-percentage-point lower employment rate for women, and a 0.1-percentage-point higher rate for each year of age), but there are no significant differences in the SCI sample. Race has an insignificant effect on employment in the New Jersey sample, but a significant one in the SCI sample.

As another point of comparison, the employment determinants of those with a self-reported work disability in the CPS sample are presented in column 3 . This sample is comparable to the general population in the negative effect of age and positive effect of marriage, but it shows a weak relationship between education and employment below the graduate school level. The overall employment rate of those with self-reported work disabilities (21.68) is less than the rate for the SCI sample $(30.18)$. The highest predicted rate is for those who have graduate degrees (61.98). Marriage has a strong positive effect, and age a strong negative effect, on the probability of employment. In general, the results indicate different influences upon employment between the SCI sample and the work disability sample.

What levels of employment would be predicted for the SCI sample if they had the same determinants of employment as the general population, and how does this compare with actual SCI employment? The bottom of Table 5 combines the demographic characteristics of the SCI sample with the coefficients from general 
population equation, generating predictions of employment levels for the SCI sample if they did not have a disability. Although only $30 z$ of the SCI sample is currently employed, 768 are predicted to be employed based on their characteristics and the model for the general population -- a difference of 46 percentage points.

It is instructive to compare the cross-sectional, probit-based estimate of the employment effect of an SCI to estimates based on other methods and data. A simple pre/post-comparison of the employment rate just for the SCI sample yields a 51 percentage point decline, from 818 employed at time of injury to 308 employed currently. And the differential in employment rates at the time of the survey between the 71 matched pairs of the SCI and non-SCI samples yields a 57 point differential ( 898 versus 328 ), whereas the difference between the pre- and post-injury change for the SCI and paired non-SCI sample is 51 percentage points. Thus, all comparisons point to a dramatic decline in employment.

Finally, we use the quarterly UI earnings records provided by the State of New Jersey to examine the dynamics of employment for the SCI and non-SCI individuals, before and after the injury. We assigned each non-SCI person a hypothetical "injury date" based on the injury date of the SCI person with the closest SSN (who likely is someone close in age because SSN'S are assigned in order of application). The employment patterns are displayed in Figure 1, which shows the ratio of the number of people for whom any earnings were reported in a particular quarter to the number who reported in any quarter. ${ }^{17}$ The

\footnotetext{
${ }^{17}$ This graph is restricted to those who reported earnings in any quarter prior to their injury date, to provide a cleaner picture of the effects of the injury on employment. Because we have no way of knowing whether SSN's in the window around the SCI person's SSN pertain to an actual person in New Jersey, this definition of the potential work force - which requires minimal employment in a 10 year period - was selected.
} 
employment patterns are tracked for five years before and after the injury. The impact of an injury on employment status is clearly illustrated in Figure 1 , where the proportion employed drops off precipitously in the quarter after the injury, and hardly grows over time. Five years after suffering an injury, only 248 of the SCI sample was employed. By contrast, the employment rate of the non-SCI sample who had pre-injury employment declines very slightly to 648 . The contrast between changes in the employment rate in the SCI and non-SCI samples yields a 40 percentage point decline in the covered employment rate for the SCI sample, which is just below the bottom of the range found above; the difference may stem from the definition of employment based on covered employment, and possibly to greater inter-state mobility of the non-SCI sample.

\section{VI, Wage and Earnings Effects of SCI}

We next examine the impact of an SCI on wage rates and earnings. Table 6 presents summary measures of earnings for the SCI sample and N.J. population (based on CPS data). For the SCI sample, there is a substantial, statistically significant difference in pre-injury pay according to whether the person became re-employed after the injury. Those who did not become re-employed post-injury earned, on average, $\$ 13.09$ per hour and $\$ 552$ per week (converted to 1994 dollars), whereas those who became re-employed earned an average of $\$ 17.82$ per hour and $\$ 821$ per week in their pre-injury job.

Column 3 shows that for those who became re-employed the average pay in the post-injury job was $\$ 16.35$ per hour and $\$ 634$ per week, representing average losses of $\$ 1.31$ /hour $(5 \%)$ and $\$ 203 /$ week (258) for those who reported in both 
Figure 1: Work Patterns Around Injury

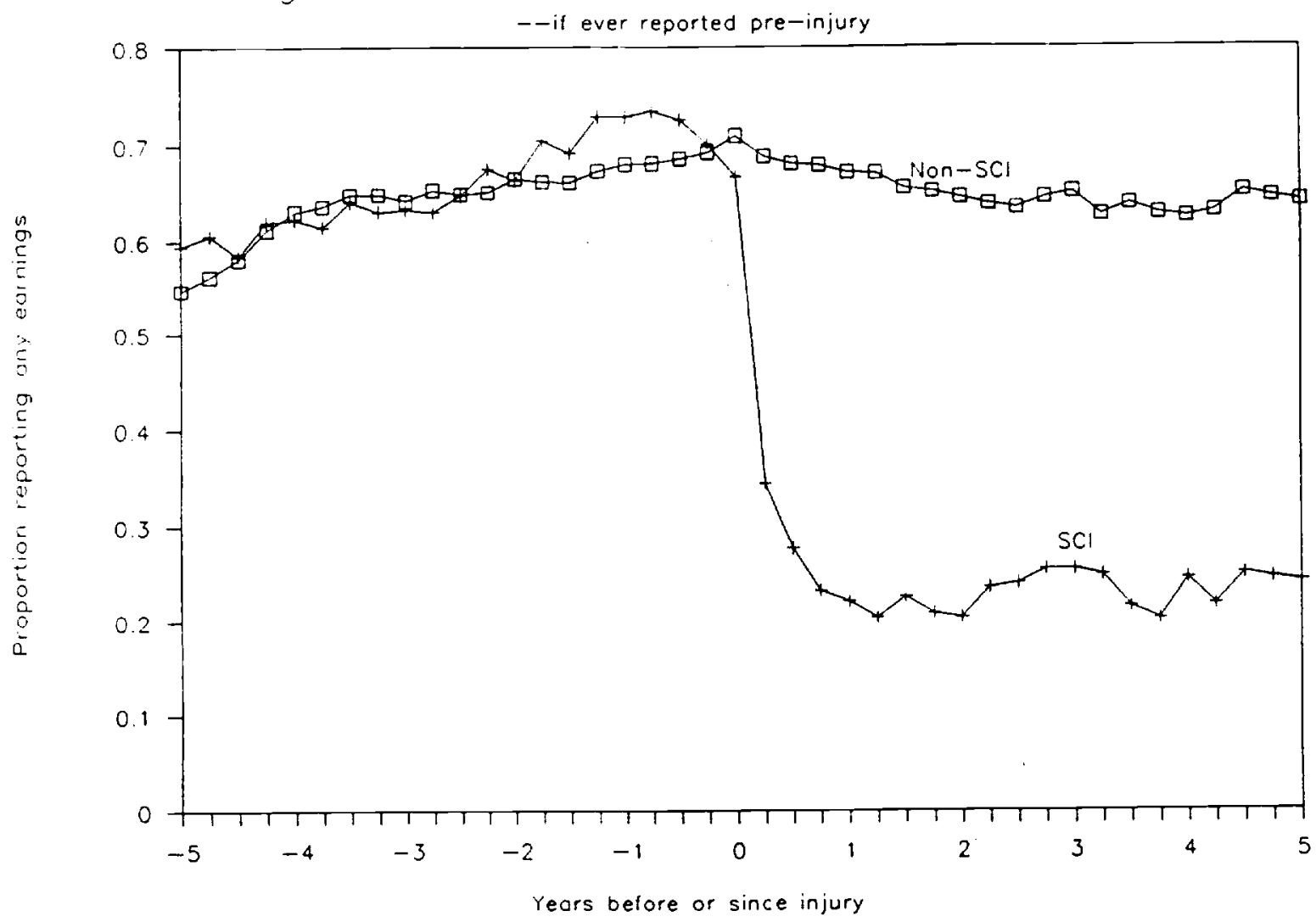


TABLE 6: Summary Employment Statistics for Full SCI Sample and General Population

\begin{tabular}{|c|c|c|c|c|c|c|c|c|}
\hline & Unit & $\begin{array}{l}\text { Not employed } \\
\text { since injury } \\
\text { Pre-injury } \\
\text { (1) }\end{array}$ & $\begin{array}{l}\text { Employed sin } \\
\text { Pre-injury } \\
\text { (2) }\end{array}$ & $\begin{array}{l}\text { Post-injury } \\
\text { (3) }\end{array}$ & $\begin{array}{l}\text { Difference } \\
\text { Nominal } \\
(4)\end{array}$ & $\begin{array}{l}\text { (post-pr } \\
\operatorname{Ln}() \\
(5)\end{array}$ & $\begin{array}{l}\text { re) } \star \star \\
\text { Percent } \\
(6)\end{array}$ & $\begin{array}{l}\text { General N.J. } \\
\text { Population, } \\
1994 \text { (7) }\end{array}$ \\
\hline Sample size* & Number & 214 & 151 & 156 & 151 & 151 & 151 & 631 \\
\hline Hourly earnings & $\begin{array}{l}\text { Mean } \\
\text { (Std. error) } \\
\text { Median }\end{array}$ & $\begin{array}{c}\$ 13.09 \\
(0.81) \\
10.06\end{array}$ & $\begin{array}{c}\$ 17.82 \\
(1.34) \\
14.48\end{array}$ & $\begin{array}{c}\$ 16.35 \\
(1.24) \\
12.82\end{array}$ & $\begin{array}{l}-1.31 \\
(1.52) \\
-0.14\end{array}$ & $\begin{array}{l}-0.05 \\
(0.06)\end{array}$ & -4.98 & $\begin{array}{l}\$ 15.64 \\
(0.48) \\
\$ 12.10\end{array}$ \\
\hline $\begin{array}{l}\text { Weekly earnings } \\
\text { (self-report) }\end{array}$ & $\begin{array}{l}\text { Mean } \\
\text { (Std. error) } \\
\text { Median }\end{array}$ & $\begin{array}{l}\$ 552 \\
(42) \\
\$ 420\end{array}$ & $\begin{array}{l}\$ 821 \\
(81) \\
\$ 640\end{array}$ & $\begin{array}{l}\$ 534 \\
(57) \\
\$ 485\end{array}$ & $\begin{array}{c}-203 \\
(82) \\
-57\end{array}$ & $\begin{array}{l}-0.28 \\
(0.10)\end{array}$ & -24.48 & $\begin{array}{l}\$ 646 \\
(21) \\
\$ 500\end{array}$ \\
\hline $\begin{array}{l}\text { Quarterly earnings***} \\
\text { (administrative data) }\end{array}$ & $\begin{array}{l}\text { Mean } \\
\text { (Std. error) } \\
\text { Median }\end{array}$ & $\begin{array}{l}\$ 5,123 \\
(357) \\
\$ 4,152\end{array}$ & $\begin{array}{r}\$ 7,544 \\
(934) \\
\$ 5,428\end{array}$ & $\begin{array}{c}\$ 6,956 \\
(816) \\
\$ 4,052\end{array}$ & $\begin{array}{c}-639 \\
(568) \\
40\end{array}$ & $\begin{array}{l}-0.24 \\
(0.11)\end{array}$ & -21.39 & $\begin{array}{l}\$ 7,475 \\
(262) \\
\$ 6,089\end{array}$ \\
\hline Hours worked per week & $\begin{array}{l}\text { Mean } \\
\text { (Std. error) } \\
\text { Median }\end{array}$ & $\begin{array}{c}40.5 \\
(0.8) \\
40\end{array}$ & $\begin{array}{c}42.4 \\
(1.1) \\
40\end{array}$ & $\begin{array}{c}35.8 \\
(1.1) \\
40\end{array}$ & $\begin{array}{c}-6.7 \\
(1.4) \\
0\end{array}$ & & & $\begin{array}{c}40.9 \\
(0.6) \\
40\end{array}$ \\
\hline Tenure & $\begin{array}{l}\text { Mean } \\
\text { (Std. error) } \\
\text { Median }\end{array}$ & $\begin{array}{c}6.4 \\
(0.6) \\
3\end{array}$ & $\begin{array}{c}6.4 \\
(0.6) \\
3\end{array}$ & $\begin{array}{c}5.1 \\
(0.5) \\
2.5\end{array}$ & $\begin{array}{c}-1.1 \\
(0.4) \\
0\end{array}$ & & & \\
\hline White-collar & Percent & $42.9 t$ & 61.58 & 83.04 & 21.54 & & & $64.7 \%$ \\
\hline Union status & Percent & 22.98 & $22.3 t$ & $11.0 t$ & $-9.6 t$ & & & 24.97 \\
\hline Health insurance from job & Percent & 54.58 & 67.34 & $55.8 t$ & -10.27 & & & \\
\hline Use computer at work & Percent & 21.78 & 36.48 & $64.7 t$ & 26.78 & & & \\
\hline Same employer as pre-injury & Percent & & & 41.78 & & & & \\
\hline Same job as pre-injury & Percent & & & 38.98 & & & & \\
\hline $\begin{array}{l}\text { Not in same job but could } \\
\text { have been with add'l. } \\
\text { training, adaptive devices }\end{array}$ & Percent & 9.38 & & 13.98 & & & & \\
\hline
\end{tabular}

Pre-1994 earnings figures have been adjusted to 1994 values using growth of mean earnings as reported in CPS (for hourly

and weekly earnings) or of mean N.J. guarterly 1994 value

* and weekly earnings) or of mean N.J. quarterly earnings.

* * Pre/post difference is calculated only for those reporting in both periods.

column 5 represents average change in natural logarithm of earnings, and column 6 translates

this value to an estimate of average percentage change.

*** Average of four most recent quarters. 
periods ${ }^{18}$ The median losses were more modest, indicating that although most respondents had losses in pay, a few large losses pulled down the average. Average quarterly earnings for the re-employed SCI sample declined by 298 . The larger drop in weekly and quarterly pay points toward fewer hours worked per week; the re-employed went from an average 42.4 to 35.8 hours worked per week. The re-employed were also less likely to be union members or have employerprovided health insurance in their new jobs ( 10 percentage point drops in both), but were much more likely to use computers at work (64.78 compared to 36.48 preinjury). A minority of those who were never employed after the injury had been in blue-collar jobs before the injury (42.98), whereas those who became reemployed after the injury were more likely to have been in white-collar jobs beforehand (61.58), and there was a further shift to white-collar jobs (particularly sales and administrative support) after the injury (83.08). Less than half of the re-employed have the same employer (41.78) or job (38.98) as in their pre-injury work, and some 98 of those who never gained work after their injury said they could have worked in their pre-injury job with additional training or adaptive devices. The switches in employers account for the lower average tenure on the post-injury job for the employed ( 5.1 compared to 6.4 years pre-injury).

Comparable data for the New Jersey general population in 1994 are provided in column 7, where it can be seen that the average hourly pay for the re-employed SCI group is higher than the population average ( $\$ 15.64 /$ hour) and their average

${ }^{18}$ The decline in pay is statistically significant for weekly pay, but not for hourly pay. The pre/post difference may not exactly match the difference between the mean values in each period because the levels reflect the largest possible sample each period, but the pre/post differences (column 4) are reported only for those who reported earnings in both periods. The top row indicates the maximum sample size. 
weekly pay is close to the population average $(\$ 646 /$ week) and average quarterly pay is lower than the population average $(\$ 7,475)$. The post-injury hours per week (35.8) and union membership (11.08) for the re-employed are also lower than general population figures ( 40.9 hours per week and 24.98 union membership).

How do the determinants of pay compare between the SCI population and the general population? Table 7 reports results of standard log-wage regressions for the general population and the SCI sample with any post-injury employment, using the current or most recent wage for the SCI sample. ${ }^{19}$ Most of the estimated coefficients are similar in the two groups. For example, the male-female pay differential is similar in both populations (about $20 \%$ lower hourly pay and $30 \%$ lower weekly pay for women). Similarly, even though education has a greater effect on employment in the SCI sample than in the general population, for those who are employed the wage premium associated with education is similar in the two groups.

Race and marriage are the two variables that appear to affect earnings most differently in the SCI population. Blacks in the general population earn $10 \%$ lower hourly pay than whites, but blacks with SCI's earn $30 \%$ lower hourly pay. Married people with SCI's appear to get more of an earnings premium in the SCI sample than in the general population. Marriage is associated with 98 higher hourly and weekly pay in the general population, but much greater hourly (438) and weekly (568) pay in the SCI sample. ${ }^{20}$

${ }^{19}$ To increase the sample size, the general population here refers to the entire U.S., not just New Jersey. We add a dummy indicating residence in New Jersey to adjust for regional differences in earnings.

${ }^{20}$ It is possible that this is tied to the high divorce rates and low marital rates following an injury; the SCI individuals with high earnings may be more likely to preserve marriages or get married. 
Table 7: Determinants of Earnings, General population and SCI Sample with Post-injury Employment

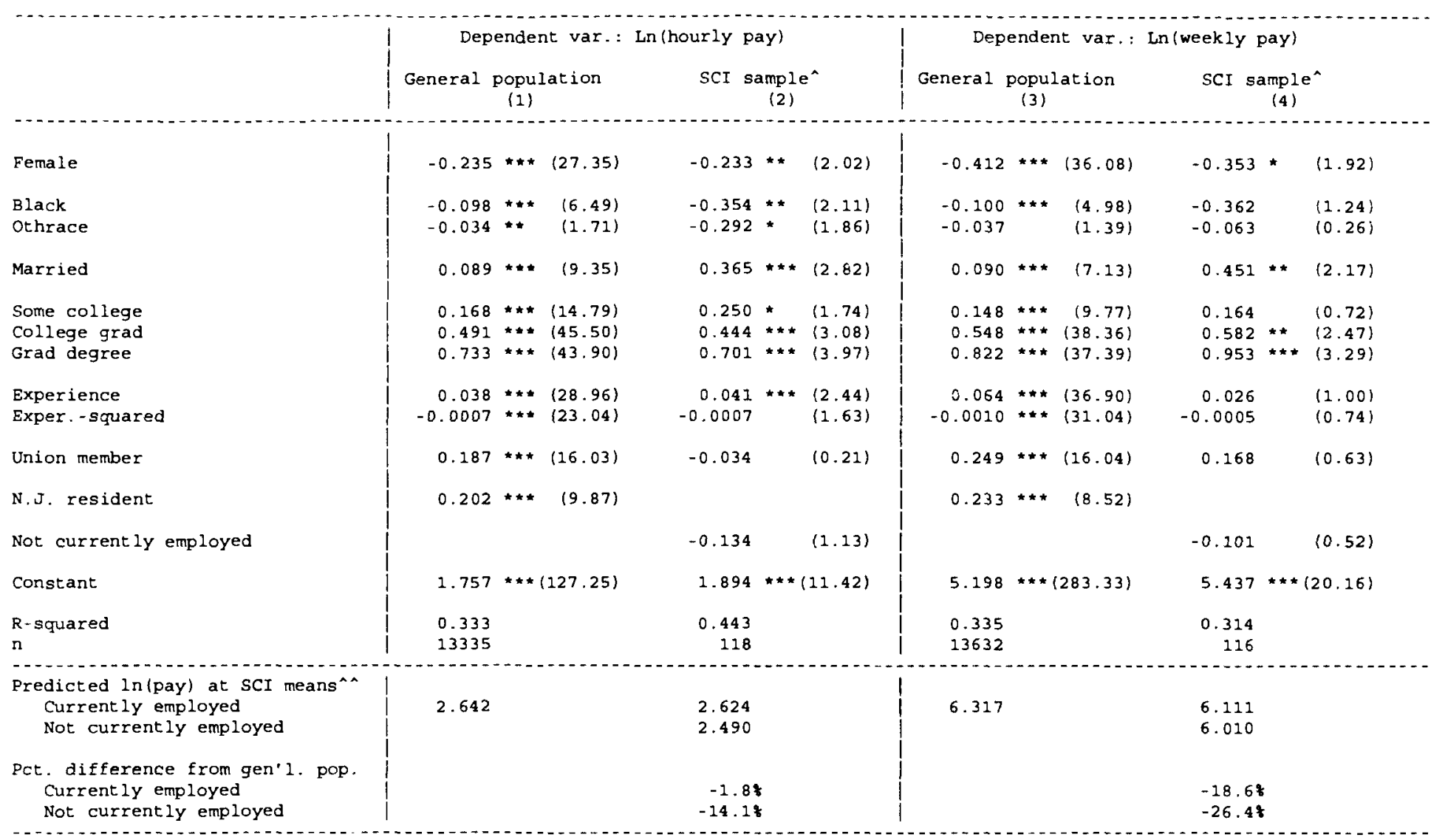

$* \mathrm{p}<.10^{* *} \mathrm{p}<.05 \quad * * * \mathrm{p}<.01$

T-statistics in parentheses.

Sample restricted to those age $18-64$.

- F-tests do not reject the equality of coefficients between the SCI and general population samples, except for the married coefficients $(p<.05)$ under both dependent variables,

$\ldots$ and the black coefficient ( $p<.10$ ) under hourly pay. for the currently employed and those who are not currently employed (but had post-injury employment) reflects the coefficient on the employment status variable in columns 2 and 4 . 
Do people with SCI's earn more or less than those in the general population with similar observable characteristics? We use the general population equation to predict earnings based on the characteristics of the SCI group, and the predictions are compared to the earnings of those with SCI's in the bottom of Table 7. There are noteworthy differences between those who are currently employed and those who are not (but did have post-injury employment). Among the currently employed in the SCI sample, there are small and insignificant differences between actual and predicted hourly earnings; however, they work fewer hours per week, as indicated by 198 lower weekly pay than that predicted based upon demographic characteristics.

\section{Earnings and Job Characteristics. Paired Sample}

How have the nominated, non-injured co-workers done since the time of the SCI person's injury? For 71 pairs, we have both pre- and post-injury data. Because the sample is so small, the results must be viewed cautiously. Nevertheless, the paired sample provides some interesting results for a uniquely matched sample, and suggests that this method may have other applications. Table 8 reports that the 33 re-employed individuals with SCI's in the paired sample had average pay losses of $\$ 1.85 /$ hour and $\$ 310 /$ week, while the nominated non-SCI group had average increases of $\$ 2.13 /$ hour and $\$ 103 /$ week over the same period. This translates into a decrease of 38 in hourly pay and $24 \%$ in weekly pay for those with SCI's, and increases of about 168 in both measures for the non-SCI group. ${ }^{21}$ Moreover, similar results hold when the sample is limited to non-SCI individuals whose matched SCI pair had post-injury employment. At the time of the survey,

\footnotetext{
${ }^{21}$ The hourly and weekly average pay increases were statistically significant for the non-SCI group, with only the decrease in weekly pay significant for the SCI group.
} 
TABLE 8: Summary Employment Statistics, Paired Sample

\begin{tabular}{|c|c|c|c|c|c|c|c|c|c|c|c|c|}
\hline \multirow[b]{2}{*}{ Variable } & \multirow[b]{2}{*}{ Unit } & \multirow{2}{*}{$\begin{array}{l}\text { SCI person } \\
\text { not employed } \\
\text { since injury } \\
\text { Pre-injury } \\
\text { (1) }\end{array}$} & \multicolumn{5}{|c|}{$\begin{array}{l}\text { SCI person } \\
\text { employed since injury }\end{array}$} & \multicolumn{5}{|c|}{ Non-SCI person } \\
\hline & & & $\begin{array}{l}\text { Pre-injury } \\
\text { (2) }\end{array}$ & $\begin{array}{c}\text { Post-injury } \\
\text { (3) }\end{array}$ & $\begin{array}{l}\text { Nominal } \\
\text { (4) }\end{array}$ & $\begin{array}{l}\operatorname{Ln}(1) \\
(5)\end{array}$ & $\begin{array}{l}\text { Percent } \\
\text { (6) }\end{array}$ & $\begin{array}{l}\text { Pre-injury } \\
(7)\end{array}$ & $\begin{array}{c}\text { Post-injury } \\
(8)\end{array}$ & $\begin{array}{l}\text { Nominal } \\
(9)\end{array}$ & $\begin{array}{l}\text { Ln (1) } \\
(10)\end{array}$ & $\begin{array}{l}\text { Percent } \\
\text { (11) }\end{array}$ \\
\hline Sample size* & Number & 38 & 33 & 33 & 33 & 33 & 33 & 70 & 70 & 69 & 69 & 69 \\
\hline $\begin{array}{l}\text { Hourly earnings } \\
\text { (self-report) }\end{array}$ & $\begin{array}{l}\text { Mean } \\
\text { (Std. error) } \\
\text { Median }\end{array}$ & $\begin{array}{l}\$ 14.67 \\
(2.28) \\
\$ 10.36\end{array}$ & $\begin{array}{c}\$ 20.67 \\
(3.56) \\
\$ 17.07\end{array}$ & $\begin{array}{c}\$ 19.07 \\
(2.21) \\
\$ 17.29\end{array}$ & $\begin{array}{l}-1.85 \\
(4.11) \\
-0.03\end{array}$ & $\begin{array}{l}-0.03 \\
(0.13)\end{array}$ & -3.08 & $\begin{array}{c}\$ 16.45 \\
(1.50) \\
\$ 13.80\end{array}$ & $\begin{array}{c}\$ 18.58 \\
(1.48) \\
\$ 15.06\end{array}$ & $\begin{array}{c}2.13 \\
(0.62) \\
1.19\end{array}$ & $\begin{array}{c}0.15 \\
(0.04)\end{array}$ & 16.28 \\
\hline $\begin{array}{l}\text { weekly earnings } \\
\text { (self-report) }\end{array}$ & $\begin{array}{l}\text { Mean } \\
\text { (Std. error) } \\
\text { Median }\end{array}$ & $\begin{array}{l}\$ 580 \\
(93) \\
\$ 465\end{array}$ & $\begin{array}{l}\$ 983 \\
(234) \\
\$ 685\end{array}$ & $\begin{array}{c}\$ 735 \\
(94) \\
\$ 777\end{array}$ & $\begin{array}{l}-310 \\
(246) \\
-\$ 57\end{array}$ & $\begin{array}{l}-0.27 \\
(0.17)\end{array}$ & $-23.7 t$ & $\begin{array}{l}\$ 721 \\
(73) \\
\$ 588\end{array}$ & $\begin{array}{l}\$ 830 \\
(72) \\
\$ 747\end{array}$ & $\begin{array}{c}\$ 103 \\
(28) \\
49\end{array}$ & $\begin{array}{c}0.16 \\
(0.04)\end{array}$ & $17.4 \%$ \\
\hline $\begin{array}{l}\text { Quarterly earnings } \star \star \star \\
\text { (administrative data) }\end{array}$ & $\begin{array}{l}\text { Mean } \\
\text { (Std. error) } \\
\text { Median }\end{array}$ & $\begin{array}{c}\$ 3,594 \\
(945) \\
\$ 2,712\end{array}$ & $\begin{array}{l}\$ 7,879 \\
(1,230) \\
\$ 7,261\end{array}$ & $\begin{array}{l}\$ 8,148 \\
(1,755) \\
\$ 7,209\end{array}$ & $\begin{array}{c}269 \\
(1,102) \\
141\end{array}$ & $\begin{array}{l}-0.31 \\
(0.35)\end{array}$ & $-26.5 t$ & $\begin{array}{l}\$ 6,713 \\
(1,043) \\
\$ 5,508\end{array}$ & $\begin{array}{l}\$ 7,534 \\
(1,042) \\
\$ 7,576\end{array}$ & $\begin{array}{c}\$ 820 \\
(602) \\
\$ 1,001\end{array}$ & $\begin{array}{c}024 \\
(0.12)\end{array}$ & 27.18 \\
\hline Hours worked/week & $\begin{array}{l}\text { Mean } \\
\text { (Std. error) } \\
\text { Median }\end{array}$ & $\begin{array}{c}41.1 \\
(2.2) \\
40\end{array}$ & $\begin{array}{c}43.3 \\
(1.7) \\
40\end{array}$ & $\begin{array}{c}35.9 \\
(2.2) \\
40\end{array}$ & $\begin{array}{c}-7.4 \\
(2.4) \\
0\end{array}$ & & & $\begin{array}{c}43.4 \\
(1.2) \\
40\end{array}$ & $\begin{array}{c}43.5 \\
(1.2) \\
40\end{array}$ & $\begin{array}{c}-0.2 \\
(0.21) \\
0\end{array}$ & & \\
\hline Tenure & $\begin{array}{l}\text { Mean } \\
\text { (std. error) } \\
\text { Median }\end{array}$ & $\begin{array}{c}7.6 \\
(1.4) \\
4\end{array}$ & $\begin{array}{c}7.6 \\
(1.2) \\
5\end{array}$ & $\begin{array}{c}6.5 \\
(1.2) \\
4\end{array}$ & $\begin{array}{c}-1.1 \\
(0.9) \\
0\end{array}$ & & & $\begin{array}{c}9.4 \\
(1.0) \\
7\end{array}$ & $\begin{array}{c}11.8 \\
(1.1) \\
10\end{array}$ & $\begin{array}{c}2.6 \\
(0.4) \\
3\end{array}$ & & \\
\hline Union status & Percent & 18.98 & 36.48 & 28.17 & -6.37 & & & 27.18 & 28.67 & 2.98 & & \\
\hline Health insurance from job & Percent & 51.47 & 81.88 & 66.78 & -15.28 & & & 74.38 & 74.38 & 1.48 & & \\
\hline Use computer at work & Percent & 28.98 & 42.48 & $60.9 t$ & $17.4 t$ & & & 42.38 & $47.6 t$ & 3.28 & & \\
\hline $\begin{array}{l}\text { Have same employer as in } \\
\text { pre-injury time } \\
\text { have same job as in } \\
\text { pre-injury time }\end{array}$ & $\begin{array}{l}\text { Percent } \\
\text { Percent }\end{array}$ & & & $60.6 \%$ & & & & & $\begin{array}{l}78.38 \\
87.08\end{array}$ & & & \\
\hline $\begin{array}{l}\text { Not in same job but could } \\
\text { have been with add' } 1 \text {. } \\
\text { training, adaptive devices }\end{array}$ & Percent & $9.1 t$ & & $15.2 t$ & & & & & & & & \\
\hline
\end{tabular}

All dollar values adjusted for earnings growth as described in note on Table 6

* Top row represents all those in category, but sample size varies for estimates due to missing data.

** Pre/post difference is calculated only for those reporting in both periods

*** Average of four most recent quarters 
re-employed SCI workers earned 158 less per hour, and $25 \%$ less per week, than their former co-workers, on average. 22

Much of the drop in average weekly pay for the re-employed SCI people in the paired sample, as with the full SCI sample, is due to reduced hours of work for those with SCI's. The non-SCI group had a trivial decline in average work hours per week ( -0.2 hours per week), while the SCI's in the paired sample had an average decline of 7.4 hours. As a consequence, the SCI person was working an average of 6.8 fewer hours per week than his or her non-SCI pair in the postinjury job (Table 8 , column 6).

How likely is it that the co-workers without SCI's maintained the same kind of work and employers since the time of the SCI person's injury? The SCI respondents in the paired sample were more likely than those in the full sample to report maintaining their pre-injury employers (60.98) and job (54.58, see Table 8 , column 3). They were less likely to be in the same job than their nonSCI pairs, however, as 78.38 of the former co-workers reported working for the same employer, and $87.0 \%$ reported doing the same kind of work as they were at the time of the injury.

\section{Quarterly Earnings Records}

We also examine earnings with the quarterly UI earnings data. Specifically, we estimate parameters of the following model:

${ }^{22}$ These differences are not statistically significant, due in part to the small sample sizes. The within-pair differences are not presented in the tables but are available. 
where $E_{1 t}$ is the quarterly earnings of person $i$ in time $t, D^{k}{ }_{i t}$ is a set of dummy variables indicating the quarter, denoted $k$, prior to or after the injury, and $S_{1}$ is a dummy variable that equals one if the individual had an SCI and zero otherwise. Again, injury dates are assigned to the non-SCI person based of tho injury date of the SCI person with the closest SSN. The coefficients $B_{k}-B^{\prime}{ }_{k}$ $(k>0)$ measure the effect of an SCI disability on post-injury earnings. The $\tau_{t}$ are time effects (i.e., coefficients on a set of 37 quarter-by-year dummies). We also include worker fixed effects $\left(\alpha_{i}\right)$ to control for permanent worker characteristics. The earnings residual is denoted by $\epsilon_{\text {it }}$, which represents omitted variables and mrasurement errors. The sample used to fit equation (1) includes both those with positive earnings and those without earnings, so the estimated effects reflect both employment and earnings trends. ${ }^{23}$ Earnings were converted to 1994 dollars based on overall mean weekly earnings growth from the CPS .

Figure 2 presents estimates of quarterly earnings based on equation (1) for the SCI sample $\left(B_{k}\right)$ and non-SCI sample $\left(B^{\prime}{ }_{k}\right)$. The figure shows a clear drop in quarterly earnings at the time of the injury, reflecting both labor supply and wage rate changes. The lack of a strong upward trend in earnings after the injury date for the SCI sample is noteworthy. Individuals who suffer an SCI appear to experience large earnings losses initially after the injury, and their earnings recover little in the first five years.

\footnotetext{
${ }^{23}$ To eliminate those who may have worked out of state or in uncovered employment, individuals with three or fewer quarterly earnings reports across the entire period are excluded from the sample.
} 
Figure 2: Earnings Around Injury

$--\mathrm{SCl}$ vs. non-SCl, fixed effects

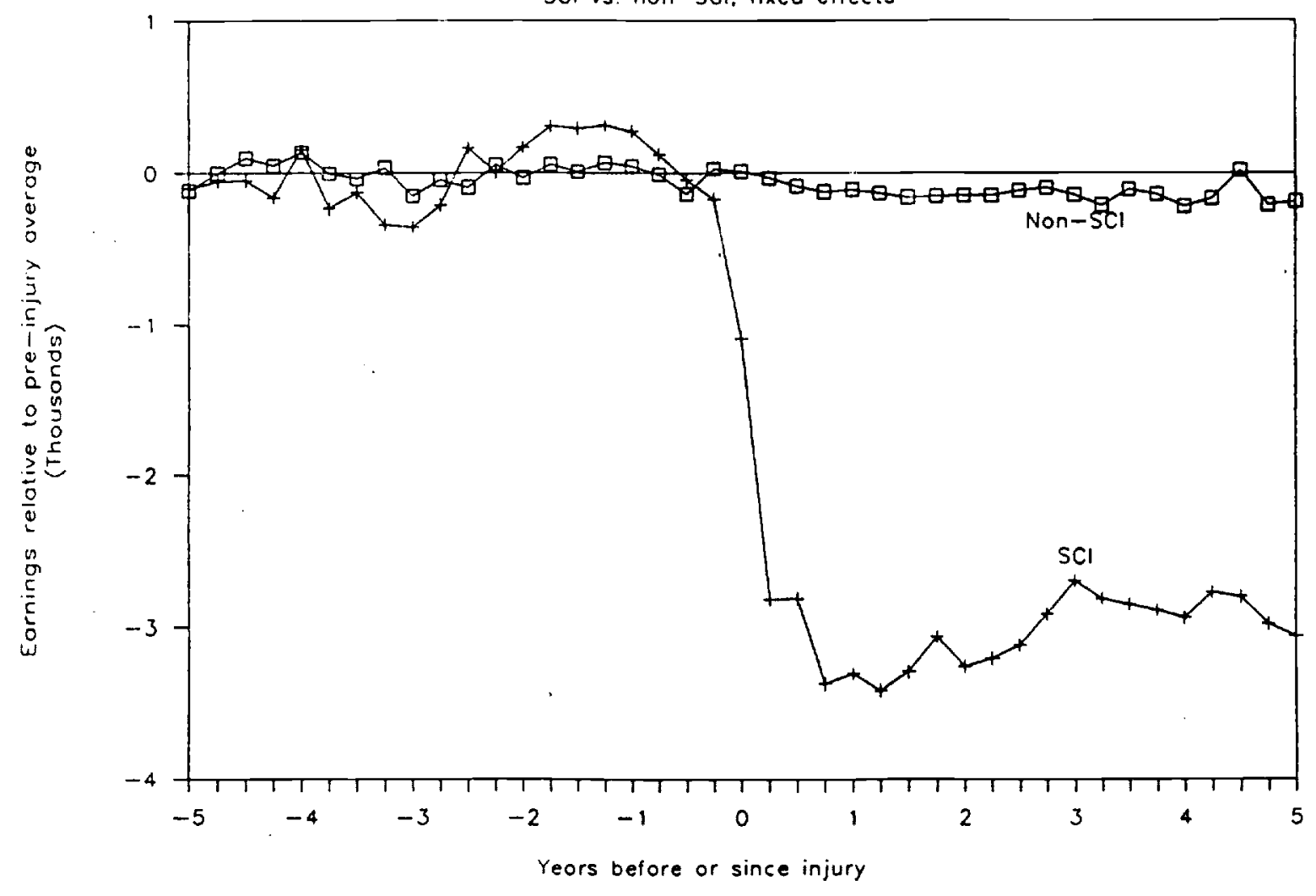


In Table 9 we report estimates of a more parsimonious model. Similar to Jacobson, LaLonde, and Sullivan (1994), we estimate the drop in earnings intially after an injury, and the linear trend in earnings beginning one year after the injury, for individuals with an SCI relative to others. Specifically, the model we estimate is:

(2) $E_{1 t}=\sum_{k<3, x^{\prime-1}} \beta_{k} D_{i t}^{k}+\sum_{k<3, \delta^{-1}-1} \beta_{k}^{\prime} D_{i t}^{k} S_{i}+\delta F_{1 t}+\delta^{\prime} F_{1 t} S_{1}+\theta T_{1 t}+\theta^{\prime} T_{1 t} S_{1}+\alpha_{i}+\tau_{t}+\epsilon_{2 t}$ where $D_{i t}^{k}$ represents dummies indicating each quarter up to (but not including) the quarter before the injury, the quarter containing the injury, and the two quarters after the injury. The variable $F_{i t}$ is a dummy that equals one in the third quarter after the injury and in all subsequent quarters, and zero before. $T_{1 t}$ is a linear spline that equals the number of years (measured to the quarter of a year) starting the first year after the injury, and equals zero before then. Notice that the model is parameterized so that the coefficients on the interactions between the SCI dummy variable $\left(S_{1}\right)$ and the other variables give the differential effects for the SCI sample versus the non-SCI sample.

We call the coefficient on $F_{1 t}, \delta^{\prime}$, the "drop" in earnings, since this is an estimate of the change in earnings from the quarter before the injury to the third quarter afterwards for the SCI's relative to the non-SCI's. We call the differential (linear) earnings growth for the SCI sample relative to the non-SCI sample beginning one year after the injury the earnings "recovery," which is measured by $\theta^{\prime}$. Different starting points for the drop and recovery variables were tested (e.g., starting recovery at six quarters after the injury), with minimal difference in the results. A prime motivation for the parsimonious model is that we can easily allow the drop and recovery to vary by demographic 
characteristics (e.g., age and gender), by interacting the demographic characteristics with the drop and recovery variables.

The first row of Table 9 reports the overall drop and recovery (i.e., without demographic interactions). The occurrence of an SCI appears to lower average quarterly earnings by $\$ 3,138$ ( $51 \%$ of the average pre-injury earnings for the most recent four quarters), followed by a small but statistically significant greater earnings growth of $\$ 82$ per quarter for each year following the injury. Extrapolating from these figures, it would take over 150 years for the average person to recover from the earnings drop following an SCI! In the other rows of columns (1) and (2) we add interactions between the drop and recovery variables and demographic characteristics to the basic model individually. In columns (3) and (4) we include all of the interactions with the drop and recovery terms in the model. The interactions suggest that the initial drop in earnings is greater for men than for women, greater for blacks, greater for workers who were older at the time of the injury, greater for those who cannot drive after the injury, greater for quadriplegics, and greater for those who did not complete high school. Additionally, earnings growth following the initial drop is more rapid for men, whites, quadriplegics, college graduates, and those who can drive.

In summary, an SCI appears to present large obstacles to becoming employed, and reduces weekly and quarterly earnings primarily by limiting average hours worked per week. But the minority of SCI individuals who are employed after the injury have similar hourly earnings to what would be predicted in the absence of an SCI. Although the occurrence of an SCI appears to reduce employment probabilities and weekly hours, the determinants of earnings for those who are employed are generally similar in the general population and SCI samples. 
Table 9: Models of Post-injury Earnings Drop and Recovery

Dependent variable: quarterly earnings (from N.J. administrative records)

Sample: 216 SCI and 4213 non-SCI individuals, with 168,302 total observations

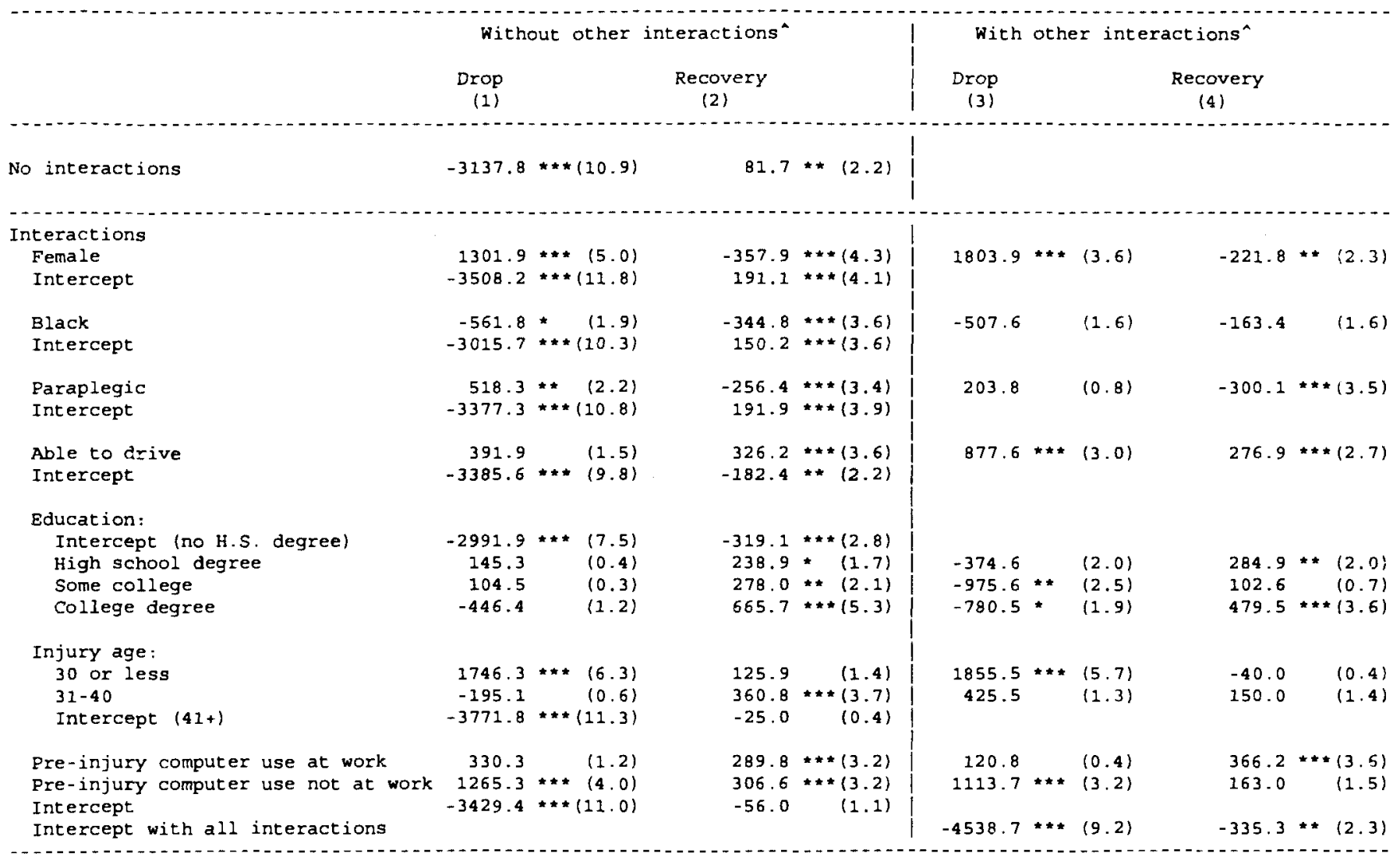

p<. 10 * $\mathrm{p}<.05$ *** $\mathrm{p}<.01$ (T-statistics in parentheses)

"Drop" = coefficient on dummy for period starting 3 quarters past injury

"Recovery" $=$ coefficient on post-injury time trend (measured in years, starting with one year post-injury)

A Estimates in columns $1-2$ based on specifications interacting drop and recovery with only one characteristic (sex, race, injury level, injury age, education, or pre-injury computer use at work), while estimates in columns $3-4$ based on one specification including interactions with all characteristics. All regressions include: person-specific fixed effects; 37 calendar quarter dummies (2nd quarter '85 to 2 nd quarter 94); dumies for the injury quarter, two following quarters, and all pre-injury quarters except for quarter preceding injury (to provide a base for earnings drop); and an equivalent set of quarter dummies, plus drop and recovery var 


\section{Aggregate Earnings Loss}

The previous estimates could be used to calculate the total annual earnings loss in the U.S. associated with SCI's. Of course, any such estimate must be viewed cautiously, as the average earnings and employment declines resulting from an SCI are estimated imprecisely. Nevertheless, this calculation provides a rough estimate of the direct earnings losses associated with SCI's, and helps to put the employment-related economic consequences of the disability in perspective. We provide two estimates: the first is based on the administrative quarterly earnings data and the second is based on our survey data.

In 1988 there were an estimated 177,000 people with an SCI in the U.S. (Harvey, et al. 1990). Although the number probably has grown since 1988, we shall use this as our base. The average earnings loss from an SCI in Table 9 was $\$ 3,138$ per quarter, or $\$ 12,552$ per year. Because this figure reflects both employment and wage effects, if we ignore earnings recovery, which was very modest, the implied aggregate earnings loss due to SCI's would be $\$ 2.2$ billion per year.

To derive an estimate of the earnings loss from the survey data, note that Table 6 shows that the average SCI person who has been employed since his or her injury earned $\$ 203$ less per week than before the injury, and 408 of people with an SCI worked at some time after their injury. The average person who did not work since his or her injury earned $\$ 552$ per week prior to the injury, in 1994 dollars. Furthermore, the estimates in Table 5 and elsewhere suggest that employment among those with SCI's declined by about 50 percentage points as a result of the injury. Thus, we assume that 408 of those with an SCI experienced a $\$ 10,556$ (- $\$ 203 \times 52$ weeks) annual loss in earnings, 508 experienced a $\$ 28,704$ 
$\left(-\$ 552 \times 52\right.$ weeks) loss, and the other 108 would not have worked any way. ${ }^{24}$ Again assuming that 177,000 people have SCI's, this yields an estimate of the aggregate earnings loss of $\$ 3.3$ billion per year.

\section{Computer Use in the SCI Sample}

Computers can be used for home shopping, home entertainment, home education, as well as "telecommuting". In 1993, nearly half of all workers directly used a computer at work. Computer devices can be adapted for people with most types of disabilities. The computer revolution is widely speculated to have greatly increased opportunities for people with disabilities. But are people with severe disabilities more likely to use computers than the rest of the population?

The paired sample of SCI and non-SCI individuals provides some insight into this issue. Some 548 of the non-SCI people responded that they currently use a computer in some capacity, while just 418 of the SCI individuals reported currently using a computer. ${ }^{25}$ The overall lower use of computers by the SCI population stems from the fact that they are less likely to work: only 208 of the SCI sample reported computer use at work compared to 428 of the non-SCI population. The percentages are close for computer use at home ( 318 among SCI and 328 among non-SCI) and school (48 among SCI and 18 among non-SCI). The proportion of those reporting ever using a computer was slightly lower for the SCI respondents (658) than their non-SCI pairs (708). Among the employed paired workers, the SCI individual was no more likely to use a computer at work prior

\footnotetext{
${ }^{24}$ This probably provides an underestimate of the earnings loss because only three-quarters of those who worked after the injury are working currently.

${ }^{25}$ The t-ratio for the difference is 1.5 .
} 
to the injury, but was 13 percentage points more likely to use a computer than the former co-worker after an injury.

What, if any, accommodations are required for those with SCI's currently using computers? A large majority reporting being capable of using a regular computer keyboard (87.28). For the one-eighth of current users who utilize adaptive devices or software, the most frequent type of adaptation is hand splints or pegs, to compensate for limited finger dexterity ( 4.48 of all current computer users, in full SCI sample), followed by voice-recognition systems for control of a computer through speaking (3.38), and adaptive software such as "sticky-key" programs that make it possible to operate a keyboard without holding down two keys at once $(1.78)$. The fact that nearly 908 of the SCI sample reported being able to dial a phone, and that a wide variety of adaptive technologies are available, make it likely that functional limitations are not an insurmountable barrier to computer use in the SCI population.

About one-fourth of the full SCI sample (26.28) received some computer training prior to their injury, and slightly fewer (22.18) received training after the injury. ${ }^{26}$ Compared to their non-SCI pairs, those with SCI's received less computer training both before and after the injury. The post-injury difference is accounted for by the lower employment rates in the SCI sample, since the prevalence of computer training is equivalent among the SCI and non-SCI individuals who have been employed post-injury.

Among those who reported training following their injury, schools (61.08) and employers (23.18) were the most common providers of training, with less than one-tenth from a rehabilitation center (8.58). Employers were the most common

\footnotetext{
${ }^{26}$ Respondents were asked about their first computer training and, if trained a second time, their most recent training.
} 
provider of training for those in the non-SCI group who received training since the time of their pair's injury.

\section{Computer Use and Earnings}

The value of pre-existing computer skills is explored in Figure 3 by comparing the earnings paths of pre-injury computer users and those who had no pre-injury computer use. This figure shows a lower drop and slightly better recovery among pre-injury computer users. The earnings equations reported in Table 9 further distinguishes pre-injury computer users according to whether they used a computer at work or outside of work. Those who used a computer at work had about the same drop in earnings as those who had no pre-injury use, but had much steeper earnings growth. Indeed, the estimates imply no earnings recovery for those who did not use a computer prior to their injury. Those who used a computer for non-work tasks prior to their injury experienced less of an initial drop in earnings and more earnings growth than the non-users of computers .

Given this pattern, one might expect computer use to be of greater value to the SCI population than to the general population. Standard log-wage equations that include as an explanatory variable a dummy variable indicating work-related computer use are presented in Table 10. Data from the October 1993 CPS - which contains comparable questions on computer use at work -- are used to estimate wage equations for the general population. Looking within each sample, computer use is associated with an hourly earnings gain of approximately 298 in the general population (column 1), and 368 in the SCI sample (column 2). ${ }^{27}$ The differential is much greater when one looks at weekly wages (.39

\footnotetext{
${ }^{27}$ See Krueger (1993) for an analysis of the payoff associated with
} computer use in the general population. 
Figure 3: Earnings Around Injury - -by pre-injury computer use

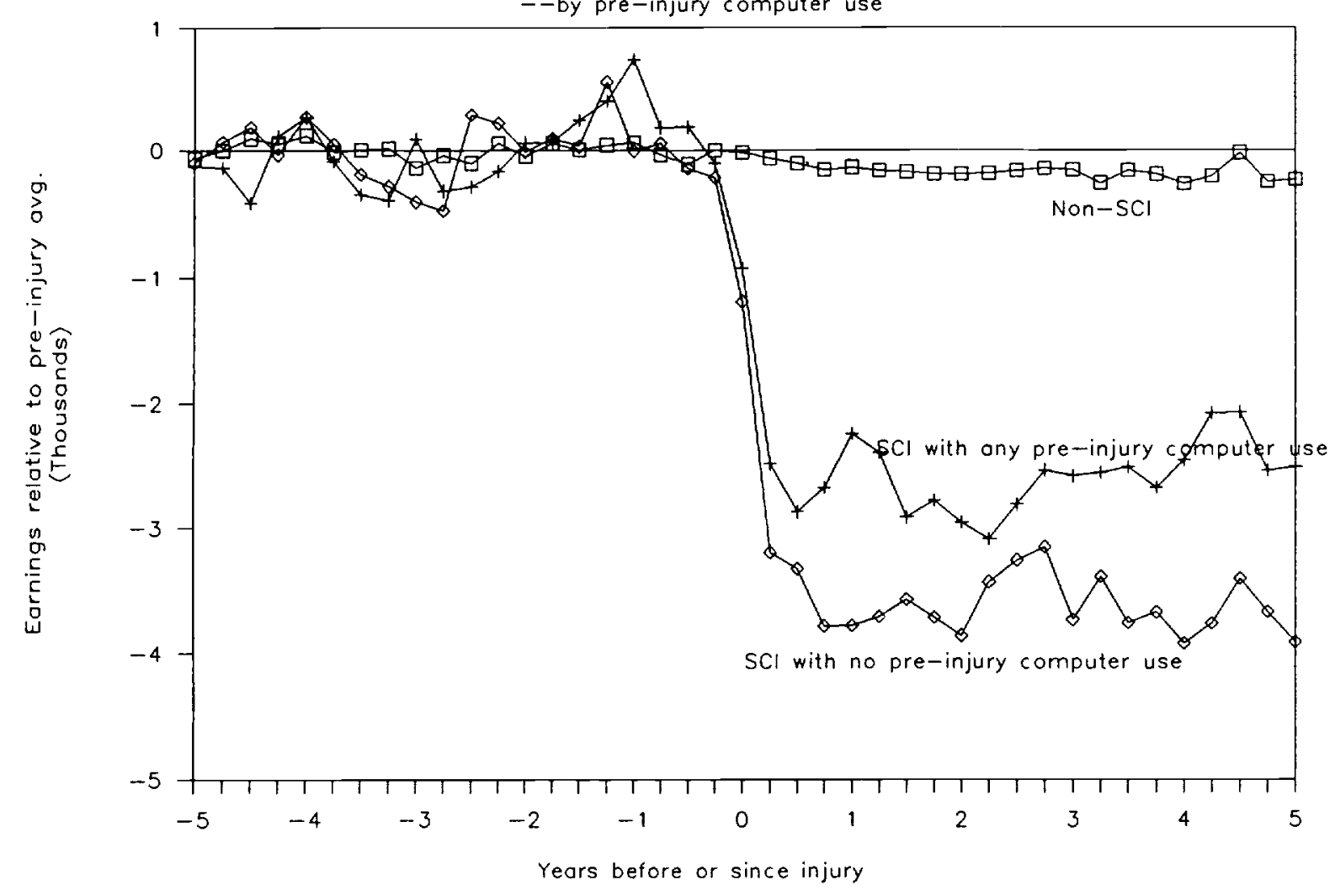


Table 10: Computer Use as Predictor of Earnings, General Population and Currently-Employed SCI Sample

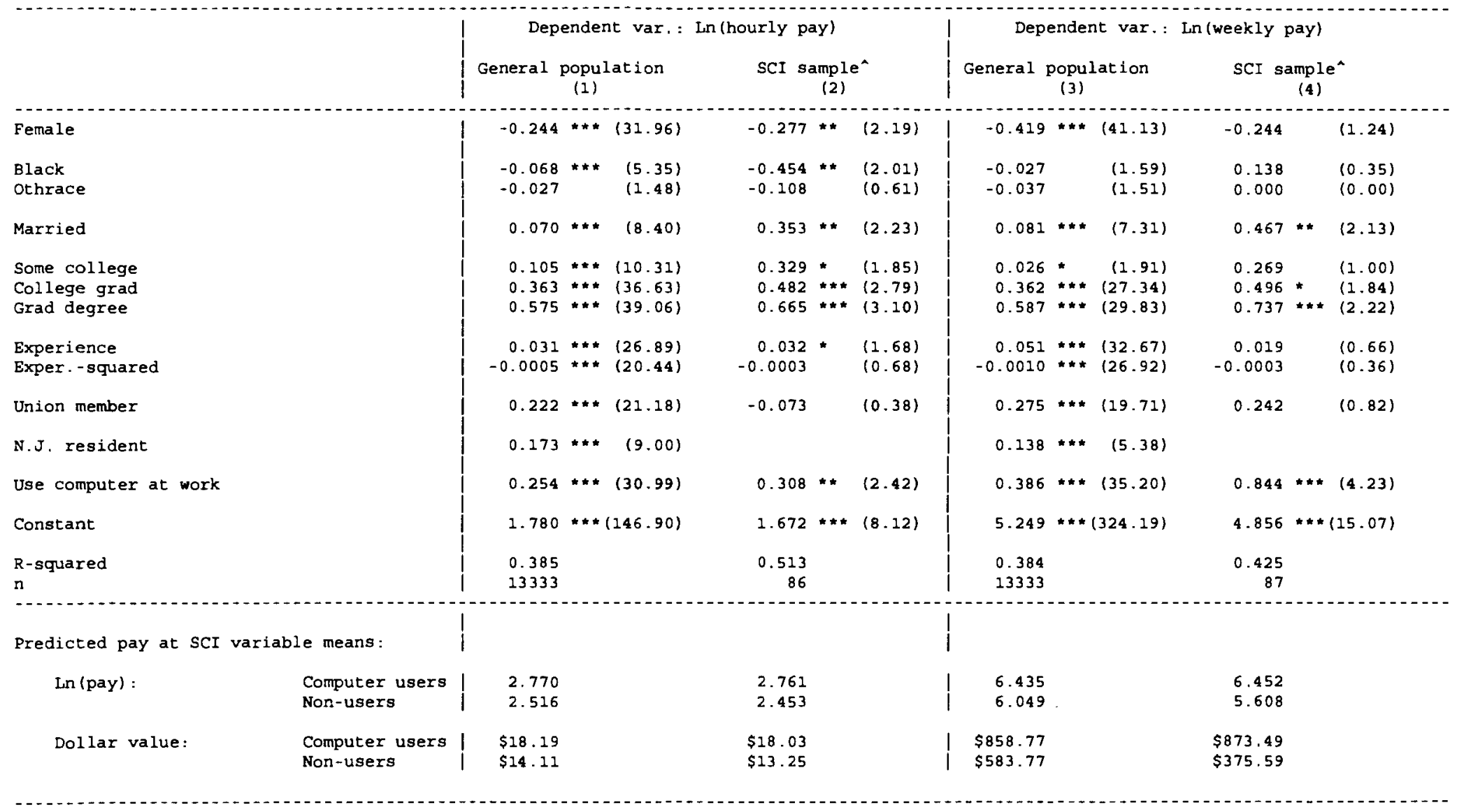

*p<.10 ** p<.05 ***p<.01 (T-statistics in parentheses)

General population sample from Current Population Survey, October, 1993. Both samples restricted to those age 18-64.

- Dollar value is calculated by exponentiating $\ln$ (pay+(.5*MSE)), where MSE = mean squared error of SCI regression estimate (.5*MSE is included under the assumption of log-normality). 
versus .84 log points) -- reflecting the fact that computer use at work is associated with substantially higher weekly work hours for the SCI sample. Moreover, the high computer premium in the SCI sample is not just an artifact of occupational differences; if eight dummies indicating broad occupations are added to the model in column 4, the computer premium increases to .88 log points.

The greater earnings advantage for computer use in the SCI sample reflects the earnings difficulties of those who do not use computers at work. The bottom of Table 10 uses the SCI means and the coefficients from the various models to calculate expected $\log$ wages by work-related computer use. Interestingly, the SCI and non-SCI models imply nearly identical predicted hourly and weekly wages for computer users, whereas workers with SCI's who don't use computers at work are predicted to over 40 percent less per week than non-users of computers in the general population with the same characteristics.

We have also explored how changes in computer use affect earnings for the SCI sample that was employed pre- and post-injury. Those who moved from a noncomputer-using job to a computer-using job (21 respondents) experienced $45 \%$ higher hourly pay, and more than 1008 higher weekly pay, relative to pay growth of those who remained in non-computer-using jobs. Using a computer in both preand post-injury work (done by 27 respondents) is associated with smaller wage gains but still significant improvement over the pay changes of the non-users, while moving from a computer-using job to one without a computer (only 4 respondents) was associated with no significant change in hourly pay but a significant decrease in weekly pay. Although the limited number of changers means that one should be cautious in interpreting these results, the pattern among the re-employed is consistent with the cross-sectional evidence that computer use at work enhances the earnings power of people with SCI's. 


\section{VIII, Conclusion}

Our results show that the occurrence of an SCI causes a steep decline in employment, hours worked, and earnings, but relatively little change in hourly wage rates for those who work. The total annual loss in earnings due to SCI's in the U.S. is estimated to be $\$ 2.2$ to $\$ 3.3$ billion. The computer revolution has the potential to greatly expand employment opportunities for individuals with disabilities. Our estimates indicate that having computer skills is associated with higher weekly and quarterly earnings for SCI individuals, with longer work hours, and with a quicker return to working following the injury, after holding constant other variables such as education. Despite the salutary effects of computer use on employment and incomes, individuals with SCI's are somewhat less likely to use computers than are those in the general population. The lower use of computers by the SCI community most likely results because most people obtain their computer training through on-the-job training, and relatively few SCI people work. 


\section{$\underline{\text { References }}$}

Berkowitz, Monroe, and William G. Johnson. 1974. "Health and Labor Force Participation," Journal of Human Resources, Vol. 9, No. 1, pp. 117-128.

Berkowitz, Monroe, Carol Harvey, Carolyn G. Greene, and Sven E. Wilson. 1992. The Economic Consequences of Traumatic Spinal Cord Injury. New York: Demos.

Bound, John. 1991. "Self-Reported versus Objective Measures of Health in Retirement Models." Journal of Human Resources, Vo1. 26, No. 1, pp. 106138 .

Bowe, F. 1987. "Making Computers Accessible to Disabled People," Technology Review, Vol. 90, pp. 52-59.

Daly, Mary and John Bound. 1995. "Worker Adaptation and Employer Accommodation Following the Onset of a Health Impairment." NBER Working Paper No. 5169.

DeVivo, Michael J., and Philip R. Fine. 1985. "Spinal Cord Injury: Its ShortTerm Impact on Marital Status," Archives of Physical Medicine and Rehabilitation, Vol. 66, August, pp. 501-504.

Disability Income Systems. 1992a. "Economic Consequences of Traumatic Spinal Cord Injury: Analysis of Post-Injury Employment Patterns, " report prepared for the Paralyzed Veterans of America (October).

- 1992b. "Living and Working with SCI: Three Years Later," report prepared for the Paralyzed Veterans of America (October).

DiTunno, John F., and Christopher S. Formal. 1994. "Chronic Spinal Cord Injury," New England Journal of Medicine, Vol. 330, No. 8, Feb. 24, pp. 550-556.

Famulari, M. 1992. "The Effects of a Disability on Labor Market Performance: The Case of Epilepsy," Southern Economic Journal, Vol. 58, pp. 1072-1087.

Freeman, Richard, and Morris Kleiner. 1990. "The Impact of New Unionization on Wages and Working Conditions," Journal of Labor Economics, Vol. 8, No. 1 (January), pp. S8-S25.

Harvey, C., B.B. Rothschild, A.J. Asmann, and T. Stripling. 1990. "New Estimates of Traumatic SCI Prevalence: A Survey-Based Approach," Paraplegia, Vol. 28, pp. 537-544.

Harvey, C., S.E. Wilson, C.G. Greene, M. Berkowitz, and T.E. Stripling. 1992. "New Estimates of the Direct Costs of Traumatic Spinal Cord Injuries: Results of a Nationwide Survey," Paraplegia, Vol. 30, pp. 834-850.

Haveman, R., and Wolfe B. 1989. "The Economic Well-Being of the Disabled," The Journal of Human Resources, Vol. 25, pp. 32-54. 
Jacobson, Louis S., Robert J. LaLonde, and Daniel G. Sullivan. 1993. "Earnings Losses of Displaced Workers," American Economic Review, Vol. 83, No. 4, September, Pp. 685-709.

Johnson, William G., and Marjorie Baldwin. 1993. "The Americans with Disabilities Act: Will It Make a Difference?" Policy Studies Journal, Vol. 21, No. 4, pp. 775-788.

Krueger, Alan. 1993. "Why Computers Have Changed the Wage Structure: Evidence from Microdata, 1984-89," Quarterly Journal of Economics, Vo1. 108, No. 1, February, pp. 33-61.

Kruse, Douglas, Alan Krueger, and Susan Drastal. 1995. The Economic Effects of Spinal Cord Injuries in the Dawn of the Computer Age. Report to the Disability Research Consortium, Rutgers University, and New Jersey Developmental Disabilities Council. New Brunswick, NJ: School of Management and Labor Relations.

Laplante, Mitchell P. and Garry E. Hendershot and Abigail J. Moss. 1992. "Assistive Technology Devices and Home Accessibility Features: Prevalence, Payment, Need, and Trend," Advanced Data, National Center for Health Statistics: Centers for Disease Control, No. 217, September 16.

McShane, Steven L., and Jeffrey Karp. 1993. "Employment Following Spinal Cord Injury: A Covariance Structure Analysis," Rehabilitation Psychology, Vol. 38 , No. 1, pp. $27-40$.

Mincer, Jacob, and Yoshio Higuchi, "Wage Structures and Labor Turnover in the United States and Japan," Journal of the Japanese and International Economies 2, 1988, pp. 97-133.

Modern Office Technology. 1989. Vol 34, p. 51.

Personnel Journal. 1990. Vol. 69, pp. 30-32.

Stern, Steven. 1989. "Measuring the Effect of Disability on Labor Force Participation," Journal of Human Resources, Vo1. 24, No. 3, pp. 361-395.

Trieschmann, Roberta B. 1988. Spinal Cord Injuries: Psychological, Social, and Vocational Rehabilitation. New York: Demos Publications.

U.S. Bureau of the Census. 1989. "Labor Force Status and Other Characteristics of Persons with a Work Disability: 1981 to 1988," Current Population Reports Series P-23, No. 160.

Wall Street Journal. 1993. "Aided by Computers, Many of the Disabled Form Own Businesses," October 8, p. Al. 